\title{
EFFECT OF DIETARY CITRIC, ACETIC ACIDS OR THEIR MIXTURE ON BROILER CHICKS PERFORMANCE, CARCASS CHARACTERISTICS AND SOME INTESTINAL HISTOMORPHOLOGICAL PARAMETERS
}

\author{
A.M.H. Abou-Ashour, Manal K. Abou El-Naga, Eman A.M. Hussein and Zeinab M.A. El- \\ Bana \\ Department of Poultry and Fish production, Faculty of Agriculture, Menoufia University, Shibin \\ El-Kom, Egypt. Email: eman.hussien@agri.menofia.edu.eg.
}

(Received 4/10/2020, accepted 16/3/2021)

\section{SUMMARY}

\begin{abstract}
A total number of $120,1 \mathrm{~d}$ old unsexed chicks were randomly distributed and divided equally into 4 dietary treatment groups with 3 replicates each. All broiler chickens were kept under similar managerial conditions. Basal starter and finisher diets were supplemented with two types of organic acids as follows: T1: basal diet (control, without supplementation), T2: basal diet $+2 \%$ citric acid (CA), T3: basal diet $+1 \%$ acetic acid (AC) and T4: basal diet $+1 \%$ citric acid $+0.5 \%$ acetic acid. Two cornsoybean based basal diets were formulated to be fed during starter ( 1 to $21 \mathrm{~d}, 22.13 \% \mathrm{CP}$ and $3088 \mathrm{Kcal} \mathrm{ME} /$ $\mathrm{kg}$ diet) and finisher (22 to $42 \mathrm{~d}, 19.82 \% \mathrm{CP}$ and $3154 \mathrm{Kcal} \mathrm{ME} / \mathrm{kg}$ diet) periods. Growth performance parameters, feed conversion ratio, some carcass characteristics and some lymphoid organs were estimated. Some blood parameters (total protein, albumin, total cholesterol, creatinine, ALT and AST) and histomorphological samples and parameters were determined at 42 day. Also, European productive and economic efficiency were calculated. Results indicated that; chicks fed diets supplemented with a mixture of citric acid $(1 \%)$ and acetic acid $(0.5 \%)$ had significantly $(\mathrm{P} \leq 0.05)$ the highest values of body weight, body weight gain and the best feed conversion ratio, while recorded the lowest feed intake compared to the other treatments. Moreover, using mixture of supplementation significantly $(\mathrm{P} \leq 0.05)$ improved performance index (PI) in comparison with the control treatment. A significant $(\mathrm{P} \leq 0.05)$ beneficial effect of citric acid and acetic acid or their mixture as feed supplementation were found concerning dressing, giblets and some immune organs percentages at $42 \mathrm{~d}$ of age compared to the control group. Mixture of citric acid and acetic acid supplementation significantly $(\mathrm{P} \leq 0.05)$ increased some serum biochemical constituents (total protein, albumin, globulin and liver enzyme; ALT), while, total lipids and cholesterol concentrations were significantly $(\mathrm{P} \leq 0.05)$ decreased. Histomorphological sections of the small intestine revealed villi height and villi widths were significantly $(\mathrm{P} \leq 0.05)$ increased with the supplementation of organic acid alone or in their mixture compared to the control group. Also, the mixture of $1 \% \mathrm{CA}+0.5 \% \mathrm{AC}$ supplementation had beneficial effects on economical efficiency. In conclusion, there are some beneficial effects of using a mixture of citric acid and acetic acid (1\% citric acid $+0.5 \%$ acetic acid) in the diets of chicks on productive performance, carcass traits, with no harm effect on health under experimental conditions.
\end{abstract}

Keywords: Citric acid, acetic acid, carcass traits, serum biochemical consituents, histomorphological parameters and broiler chicks.

\section{INTRODUCTION}

A modernistic challenge in the poultry production is to exploit the use of specific dietary supplements to boost the intrinsic potential of poultry for better growth. The nutritional and health status of birds are largely influenced by their gut health, which affects digestion, absorption, and metabolism of nutrients, as well as disease resistance and immunity (Yegani and Korver, 2008).

High levels of production and efficient feed conversion are critical to modern poultry industry, which could be achieved by using specific feed additives. Some of the commonly used feed additives are organic acids, probiotics, prebiotics, medicinal extract and exogenous enzymes. These feed additives were used as antimicrobial, antioxidants, emulsifiers, binders and $\mathrm{pH}$ control agents in the poultry diet (Rehman et al., 2016; Jasim and Fehan, 2017; Attia et al., 2018 and Adhikari et al., 2020). 
Organic acid treatments composed of individual acids or blends of several acids to perform antimicrobial activities similar to those of antibiotics (Wang et al., 2009). The European Union allowed the use of organic acids and their salts in poultry production because these are generally considered safe (Adil et al., 2010). Organic acids are week acids, which modulate the intestinal pH. When these compounds are used correctly a long with good nutritional, management and biosecurity measures, they could be a powerful tool in maintating the health of the gastrointestinal tract (GIT) in poultry thus improving the performance ( Sabour et al., 2019 and Adhikari et al., 2020). Organic acids had higher globulin concentration and better immune response and reduced serum cholesterol and total lipid (Youssef et al., 2017; Ali et al., 2019 and Mirderikvandi et al., 2019).

Citric acid (CA) is the most common organic acid used in poultry diets. It acts as a growth promoter through acidifying the gastrointestinal (GI) content. CA is an organic acid that has been recently employed to improve feed utilization and its influence seems to depend on the diet composition (Mohammadi and Khosravinia 2015 and AL-Harthi and Attia, 2016). In addition, citric acid was found to change the gut PH and increase the activity of some enzymes that need acidic conditions, such as pepsin and phytase, therefore enhancing the utilization of protein and some minerals (Wickramasinghe et al., 2014), increasing the digestibility of protein and fibre (Atapattu and Nelligaswatta, 2005), improving live weight gain, feed conversion effieciency and absorpition of minerals

(Sharifuzzaman et al., 2020). Citric acid also decreased pH of ceacal digesta (Jozefiak and Rutkowski, 2005), crop and gizzard (Andrys et al., 2003) and intestine (Dehghani and Jahanian, 2012 and Attia et al., 2018) in broiler chicks. It reduced microbial load and result in better immune response in broilers (Wickramasinghe et al., 2014).

Acetic acid are among greater attention for poultry industry (Kral et al., 2011 and Mohammadi et al., 2018). It is generally belived that use of acetic acid in broiler diets may inhibit pathogens like salmonella in both raw material and feed (Choct, 2001). The lower PH created can protect the animal from infection especially at their younger ages (Mohammadi et al., 2018). Acetic acid at a wide dose range from 0.5 to $5 \%$ has been implemented in diets for broiler chickens which mainly reduced growth of many pathogenic or non- pathogenic intestinal bacteria, therefore, reduced the risk of intestinal colonization and infectious processes, ultimately decrease inflammatory processes at intestinal mucosa, a phenomenon which in turn, increase villus highet and function of secretion, digestion and absorpition of nutrients by the mucosa (Pelicano et al., 2005). Acetic acid (AC) supplementation in diet improves growth performance (Seifi et al., 2015 and Abdel Razek et al., 2016), quicken intestinal tissue, resulting in changes in villus width, height and area of the duodenum, jejunum and ileum, which all are the promising factors for the better intestinal health and nutrient digestion and absorpition (Kum et al., 2010; Mohammadagheni et al., 2016 and Saleem et al., 2016). Citric acid (CA) and acetic acid (AC) have been used in diets due to their positive effect on bird's health and growth (Islam et al., 2008).

Therefor, the objective of the present study was to investigate the effects of dietary supplementation of some organic acids such as citric, acetic or the mixture citric and acetic at the levels of 2,1 , or 1 and $0,5 \%$, as respectivily on growth performance, carcass characteristics, intestinal histomorphology, some serum blood parameters and economic efficiency in broiler chicks.

\section{MATERIALS AND METHODS}

The present study was conducted in a private farm in Menouf, Menoufia Governorate, Egypt, throughout the experimental period from May to June 2018 to study the effect of dietary supplementation of some organic acids (citric or acetic acids and their mixture) on growth performance, carcass characteristics, some histomorphological measurements, some serum biochemical parameters and economic efficiency of broiler chicks.

\section{Experimental diets:}

Two corn-soybean based basal diets were formulated to be fed during starter (1 to $21 \mathrm{~d}$ ) and finisher ( 22 to $42 \mathrm{~d}$ ) periods. The broiler diets were formulated to be approximately isocacloric and isonitrogenous and meet or exceed the nutritional requirements according to National Research Council's nutrient (NRC, 1994) and used to formulate the basal diet (Table 1). The basal corn - soybean meal starter diet contained approximately, 22.13\% CP and 3088.38 Kcal ME/kg diet and 19.82\% CP and $3154 \mathrm{Kcal} / \mathrm{kg}$ in finisher diet and both were offered in mash form. Proximate chemical analysis of the basal diets fed was performed according to AOAC (2011). Basal starter and finisher diets were supplemented with two types 
of organic acids, ( $\mathrm{OA})^{*}$ as: citric acid, (CA) and acetic acid, (AC) as follows:

$\mathbf{T}_{1}$ : basal diet (control, without any supplementation).

$\mathbf{T}_{2}$ : basal diet $+2 \%$ citric acid.

$\mathbf{T}_{3}$ : basal diet $+1 \%$ acetic acid.

$\mathbf{T}_{4}$ : basal diet $+1 \%$ citric acid $+0.5 \%$ acetic acid. Mixing of experimental diets was done weekly.

\section{Chicks assay procedures:}

On the day of hatch, one hundred and twenty, mixed sex Arbor Acres chicks were used in this experiment. Chicks were wing banded, weighed and randomly allotted to four treatment groups, 3 replicates of 10 chicks each nearly similar in initial body weight ( $45 \mathrm{~g})$. Groups were reared in pens with litter (wheat straw) from 1 day old up to 42 days of age.

Throughout the experimental period (42d), chicks were given feed and water ad libitum. The management of broiler chickens was consistent with the guidelines (Arbor Acres Broiler Commercial Management Guide; http: //en. aviagen.com/assets/Tech_Center/AA_Broiler/AA-BroilerHandbook2014i-EN.pdf). A $23 \mathrm{~h}$ of light and $1 \mathrm{~h}$ of darkness lighting schedule was maintained for the duration of the experiment. The initial temperature was $33{ }^{\circ} \mathrm{C}$ at the first day of age and decreased approximately $2{ }^{\circ} \mathrm{C} /$ week until $24{ }^{\circ} \mathrm{C}$, which was maintained at this temperature till the end of the experiment. Temperature, humidity, light and ventilation were the same for all treatments. Vaccination was performed according to breeder standards and was the same for all experimental treatments. All proper husbandry practices were followed.

\section{The following parameters were measured:}

Body weight (BW) an individual body weight was recorded while, body weight gain (BWG) and average daily gain $(\boldsymbol{A D G})$ were calculated from the first day of the experiment and by weekly throughout the experimental periods.

Feed intake and feed conversion ratio:Total feed intake / dietary treatment group / day was recorded and expressed as feed (g) / bird / day. Feed conversion ratio was expressed as feed $(\mathrm{g}) /$ body weight gain $(\mathrm{g})$.

Performance index (PI), mortality ratio (MO) and livability (Liv), \%:

Performance index was calculated according to North (1984) as follows:

$\mathrm{PI}=$ Live body weight gain $(\mathrm{Kg}) \times 100 /$ feed conversion ratio .

Mortality was recorded during the experimental periods, mortality $\%$ was calculated by subtracting the number of live birds at the end of the experiment from the total number of birds at the begining of the experiment. The product was multiplied by 100 to obtain the percentage mortality $\%$ as follow: MO, $\%=$ (No. of birds at the begining of a given period - No. of birds at the end of the same period) $\times 100 /$ No. of birds at the begning of a given period. Livability $(\operatorname{Liv}, \%)=$ No. of birds at the end of the experiment period $\times 100 /$ No. of birds at the beginning of the experiment.

\section{Slaughter and carcass information:}

At the end of 42 days of age, three birds from each dietary treatment were weighed and slaughtered, after feed withdrawal for 12 hours to determine carcass traits: eviscerated carcass (without head, neck and legs) and total giblets (liver, gizzard and heart) weights were expressed relative to live body weight.

The bursa of fabricius, spleen and thymus (all lobes from left side of the neck) were cut and weighed to the nearest milligram. Data obtained was used for the calculation of dressing percentage as follows:

Dressing percentage $(\%)=$ carcass weight $\times 100 /$ live weight of bird.

\section{Serum samples and biochemistry parameters:}

Blood samples were taken at slaughter time from each bird, individual blood samples were collected. into tubes without heparin and serum was separated by centrifugation at $3500 \mathrm{rpm}$ for 15 minutesand frozen at $-20^{\circ} \mathrm{C}$ until analysis Serum total protein (TP), albumin (A), total lipids (TL), cholesterol (Chol.), creatinine and glucose were determined using commercial kits. The globulin $(\mathrm{G})$ value was obtained by subtracting the values of albumin from the corresponding values of total protein. Also, albumin/ globulin (A / $\mathrm{G}$ ratio) values were obtained by dividing the values of albumin on the values of globulins according to Coles, (1974). Also, liver function enzymes including aspartate amino transaminase (AST) and alanine amino transaminase (ALT) were calorimetrically estimated according to Reitman and Frankel (1956).

*Organic acids, citric acid (CA) was supplied from Egyptian Company for Laboratory Services, Cairo, Egypt and Acetic acid, AC powder was obtained from AVITASA (ESP43100164) I C. Europa s/n pol Constanti (Tarragona) Spain and sale only from EVPCO group, Egypt veterinary pharmaceuticals company for animal and poultry feeding line only, Alexandria, Egypt. 
Table (1): Composition and chemical analysis of the experimental diets fed during starting (1 -21) and finisher periods $(22-42)$ days of age.

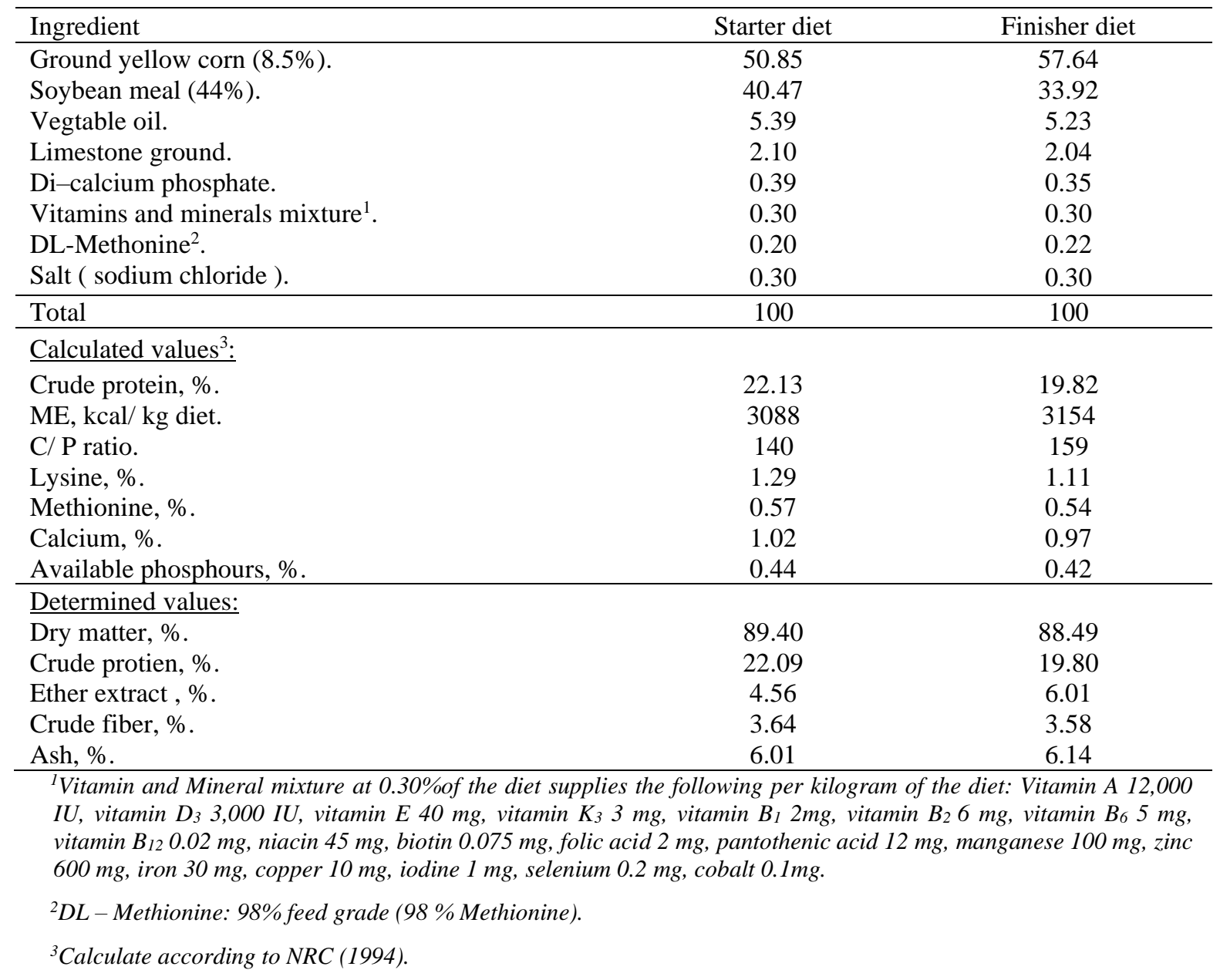

\section{Histomorphological samples and parameter:}

For the histological study of intestinal villi, at 42 days age, samples of duodenum, jejunum and ileum were obtained from the slaughtered birds. The specimens was $2 \mathrm{~cm}$ of the middle portions of the duodenum, jejunum and ileum were excised and fixed in $4 \%$ buffered formalin (Bancroft et al., 1996). Segments referred to the midpoint of the duodenum (from gizzard to pancreo-biliary duct), jejunum (the midpoint between the entry of the common bile duct and the Meckel's diverticulum) and ileum (from the Meckel's diverticulum to ileocecal junction). Particular segments were gently flushed and rinsed with $0.9 \%$ physiological saline and then fixed in $4 \%$ neutral-buffered formalin solution for histological study.

Samples of the small intestine were transferred from formaldehyde after dehydration through passing tissue by sequences of alcohol solutions and then were cleared by xylene and embedded in paraffin. These fragments were opened longitudinally on styrofoam plates and washed with saline. The samples were fixed with Bouin's solution for $24 \mathrm{~h}$ for histological analysis, according to Uni et al. (1999). The fragments cuts of $5 \mu \mathrm{m}$ thick and stained with Hematoxylin and Eosin (H \&E).

Morphmetric data from villus height and crypt depth were obtained from images captured by photomicroscope (Olympus).The tissue sections were taken for measuring the villus height, villus width and crypt depth. Morphometric measurements were performed on the selected 9 villi from each sample. The height of intestinal villi was measured from the tip to the base of villi at the opening crypt, and the villus width was measured at its midpoint (Geyra et al., 2001). The intestinal crypt depth was measured from the base of the villi to submucosa, and the muscular thickness from the submucosa to the external layer of the intestine (Ebrahimi et al., 2017). 
Economical efficiency, relative economical efficiency and European productive efficiency, (\%):

The economic efficiency was calculated from the input - output analysis (Heady and Jensen, 1954) assuming that other head costs were constant, as follows: [(price of $\mathrm{kg}$ weight gain-feed cost $/ \mathrm{kg}$ gain)/ feed cost $/ \mathrm{kg}$ gain $\times 100]$ under the experimental conditions and European productive efficiency was calculated as: $\quad$ EPE, $\%=($ Mean body weight $(\mathrm{Kg}) \times$ livability $\% \times 100) /$ feed conversion ratio $\times$ marketing age, days), a cited by Soltan and Kusainova, (2012).

Statistical Analyses:

The experiment was conducted using a completely randomized design using SPSS (2011) program and the difference among treatment means were determined using Duncan's multiple range test (Duncan, 1955). Percentages were transformed to the corresponding arcsine values before performing statical analysis (Snedecor and Cochran, 1982) the following statical model was applied:

$$
\mathrm{Yij}=\mu+\alpha \mathrm{i}+\text { Eij. }
$$

Where:

$$
\begin{aligned}
& \text { Yij = Observed traits, } \\
& \mu=\text { Overall mean, } \\
& \alpha \mathrm{i}=\text { Effect of treatment }(\mathrm{I}=1,2,3 \text { and } 4) \text { and }
\end{aligned}
$$

Eij= Experimental random error.

\section{RESULTS AND DISCUSSION}

\section{Effect of dietary citric acid (CA), acetic acid (AC) or their mixture on broiler performance:}

\section{Body weight, weight gain and daily gain:}

The effect of dietary citric acid (2\% CA), acetic acid $(1 \% \mathrm{AC})$ or their mixture $(1 \% \mathrm{CA}+0.5 \% \mathrm{AC})$ supplementation on body weight (BW), body weight gain (BWG) and average daily gain (ADG) of growing broiler chickens up to 42 days of age are shown in Table (2). The data showed a significant $(\mathrm{P} \leq$ $0.05)$ increased in body weight for birds fed dietaries $2 \% \mathrm{CA}\left(\mathrm{T}_{2}\right)$ and $1 \%$ acetic acid $\left(\mathrm{T}_{3}\right)$ or their mixture of organic acids $\left(\mathrm{T}_{4}, 1 \% \mathrm{CA}+0.5 \% \mathrm{AC}\right)$ being $1232.23,1220.06$ and $1262.50 \mathrm{~g}$, respectively compared to $1218.45 \mathrm{~g}$ in the control group. As for BWG and ADG (Tables 2), chicks fed basal diets without supplementation had significantly lower $(\mathrm{P} \leq 0.05)$ body weight gain $(751.74 \mathrm{~g})$ and ADG $(53.79 \mathrm{~g})$ during the period from 28 to 42 days of age. Broiler chicks fed $2 \%$ CA, $1 \%$ AC supplementation have the heighest BWG being (795.11 and 775.36g) and ADG values were $56.79 \mathrm{~g}$ and $55.50 \mathrm{~g}$ for $\mathrm{T}_{2}$ and $\mathrm{T}_{3}$, respectively during the period from 28 to 42 days of age, body weight gain and average daily gain were significantly increased $(\mathrm{P} \leq 0.05)$ with the mixture of citric acid and acetic acid supplementation being; 812.63 and $58.07 \mathrm{~g}$, respectively for $\mathrm{T}_{4}$ compared to other treatment and control group.

In general, birds fed dietary the mixture of $1 \% \mathrm{CA}+0.5 \% \mathrm{AC}\left(\mathrm{T}_{4}\right)$ or chicks fed dieary $1 \% \mathrm{AC}\left(\mathrm{T}_{3}\right)$ followed by those fed $2 \%$ CA supplementation $\left(\mathrm{T}_{2}\right)$ had the greatest BW, BWG and ADG, being (2075.13, 1995.42 and 2027.34g) for BW at 42 days of age; 2029.97, 1982.53 and 1948.15g in BWG and for ADG; were 50.02, 47.36 and $46.28 \mathrm{~g}$, respectively during the period frome $1-42$ days of age compared to 1970.19 for BW at 42 days of age, 1924.98 and 46.13g for BWG and ADG, respectively for the control group during the period from 1 to 42 of age.

The improvement in BW, BWG and ADG of broilers fed diet contain of citric acid, acetic acid or thire mixture may be due to the following reasons a) acetic acid acts on pepsinogen and convert it to pepsin and increased the activity of pepsin and improves protein digestibility in broiler chicks (Ulaiwi et al., 2017), b) the antimicrobial property and low $\mathrm{pH}$ of organic acid inhibits the pathogenic intestinal bacteria and decreases the level of toxic bacterial products. So, energy and protein digestibility were improved (Adil et al., 2011 and Sultan et al., 2015), c) organic acids improve the protein digestibility by decreasing endogenous nitrogen losses and production of ammonia as well as other growth depressing metabolites (Dibner and Buttib 2002), d) intestinal cell proliferation and hence more available nutrients for absorption (Samanata et al., 2010), and the acidic condition increases the nutrients availability for better performance (Boling et al., 2001). Acetic acid has more effects on performance of broiler, addition of acetic acid to mash diet may lead to increase in palatability and improve mixing ration items 


\section{Abou-Ashour et al.}

(Mohammadagheni et al., 2016). These results were a greement with the results reported by Khan and Iqbal (2016) and Youssef et al. (2017), who recorded that an improvement in BW and BWG for birds fed diets supplemented with organic acids meantime the growing period, which was due to the effect of keeping the beneficial bacteria population, improving nutrient digestion and may be impact the safety of microbial cell membrane or prohibit the nutrient transport and energy metabolism causing the bactericidal effect (Ricke, 2003). Many investigators reported that single or mixture of organic acid (CA and AC) can improve performance of chicks and had a significant effect of mean BW, WG and ADG on broiler chicks (Sabour et al. (2019); Adhikari et al., 2020; Sharifuzzaman et al., 2020 and Stamilla et al. (2020). On the other hand, Kopecky et al. (2012) and Flamand et al. (2014) showed that organic acid (citric and acetic acids) addition to the corn- soybean diet did not affect chick body weight, body weight gain and average daily gain.

\section{Feed intake (FI), feed conversion ratio (FCR) and performance index (PI):}

Data describing the effect of dietary organic acid as citric, acetic acids or their mixture on feed intake (FI, g / chick/ day) of broiler chickens during the period from 1 - 42 days of age are presented in Table 3. Broiler chickens fed citric and acetic acid supplemented to the basal diet significantly affect the feed intake of the treated- groups compared to the control group during 1 - 14 days. Also, basal diet contained citric acid and acetic acid (1\% CA $+0.5 \%$ AC) significantly $(\mathrm{P} \leq 0.05)$ decreased feed intake of ArborAcres chicks during the experimental periods (14 - 28 days of age. Values of FI (g / chick / day) being; $90.17 \mathrm{~g}$ compared to other treatments $\mathrm{T}_{2}(2 \% \mathrm{CA}), \mathrm{T}_{3}(1 \% \mathrm{AC})$ and control group $(0$, without supplementation) being, 91.14, 93.45 and 95.71, respectively during 14- $28 \mathrm{~d}$. Feed intake (FI) for treatments $\mathrm{T}_{2}, \mathrm{~T}_{3}$ and $\mathrm{T}_{4}$ were $128.01,132.08$ and $125.33 \mathrm{~g}$ ), respectively compared to $133.16 \mathrm{~g} / \mathrm{chick} /$ day for control group at $28-42$ days of age. In general, during the entire experimental period from $1-42$ days of age, chicks fed the basal diet with $1 \% \mathrm{CA}+0.5 \% \mathrm{AC}\left(\mathrm{T}_{4}\right)$ had significantly decreased feed intake $90.11 \mathrm{~g} / \mathrm{bird} / \mathrm{d}$ in comparsion with the control group (95.67) and other experimental groups being, 91.45 and $93.96 \mathrm{~g} / \mathrm{b} / \mathrm{d}$, respectivelyduring the period from $1-42$ days of age.

The reduction in feed intake ( $\mathrm{g} /$ chicks / d) was noticed during the starter and finisher period, this may be due to the decrease in palatability of acidified diets during experimental diets. They had a low tendency to free their $\mathrm{H}^{+}$ions and thus tended to have a strong taste associated with them which might have decrease the palatability feed and resulted in reduced feed intake Abdel Fattah et al. (2008); Adil et al. (2010) and Allahdoa et al. (2018). Also, organic acids increase the availability of nutrients from the feed which in turn decrease the feed consumption Pakhira and Samanta (2006) and sultan et al. (2015). These results is harmony with the results of Abdel Razek et al. (2016) who reported that chicks fed diets supplemented citric acid and acetic acid significantly consumed less feed $(\mathrm{P} \leq 0.05)$ compared to control group. It was observed that the lowest $(\mathrm{P} \leq 0.05)$ amount of feed intake was recorded for birds fed diets containing (1.61 and 1.70) of CA and (1.98 and 2.30) of AC. Additionally these results were in line with the finding of Ali et al. (2019); Mirdrikvandi et al. (2019); Omidi et al. (2020) and Stamilla et al. (2020) who reported decreased feed intake with higher level of organic acids such as citric and acetic acids application. On the other hand, the present results disagreed with those observed by Wickramasinghe $e t$ al. (2014), Seifi et al. (2015) and Araujo et al. (2018) who reported that adding different levels of citric acid and acetic acid to broilers did not have effect on feed intake. Results in Table 3 presents the effect of dietary different levels of citric acid, acetic acids or their mixture supplementation on feed conversion ratio (FCR) during the experimental periods from 1 to 42 days of age. Data revealed that FCR was significantly improved by the supplementation during the experimental period (1- 42 days of age).

Chicks consuming the basal control diet $\left(\mathrm{T}_{1}\right)$ had FCR 2.08 during 1 - 42 days of age, but feed conversion ratio was improved gradualy with the supplementation of citric acid (2\%CA) and acetic acid (1\% AC). The best value of FCR was 1.83 for chicks fed diet supplemented with themixture of citric and acetic acids ( $1 \% \mathrm{CA}+0.5 \% \mathrm{AC})$ at $1-42$ days of age. The significant improvement in FCR by the addition $\mathrm{CA}$ and $\mathrm{AC}$ may be due to: a) organic acids as the plays a very important role that acidification increasing gastric proteolysis and protein / amino acid digestibility by enhancing digestive system enzyme activities (Langhout, 2000).

The reason why protein is better used when CA is added to diets is due to the fact that pepsinogen is converted to pepsin, which increases pepsin activity and improves protein digestibility. Morever, peptides a rising from pepsin proteolysis trigger the release of hormones (including gastrin and cholecystokinin) which regulate the digesion and absorption of protein, b) organic acids due to the increasing efficiency of nutrients (Chowdhury et al. 2009), c) the numerical reduction in feed intake and concomitent increase in 
BWG (Dehghani and Jahanian 2012) and d) organic acids due to the metabolic role of CA and AC in many metabolic path ways (Attia et al., 2013).

Table (2): Effect of dietary citric acid, acitic acid or their mixtur supplementation on body weight, body weight gain and daily weight gain of broiler chicks during experimental periods ( Means \pm S.E.).

\begin{tabular}{|c|c|c|c|c|c|c|}
\hline \multirow{2}{*}{ Dietary treatments ${ }^{1}$} & \multicolumn{2}{|c|}{ Body weight } & \multicolumn{2}{|c|}{ Body weight gain } & \multicolumn{2}{|c|}{ Average daily gain } \\
\hline & $\begin{array}{c}28 \\
\text { days of } \\
\text { age }\end{array}$ & $\begin{array}{c}42 \\
\text { days of age }\end{array}$ & $\begin{array}{c}28-42 \\
\text { days of age }\end{array}$ & $\begin{array}{c}1-42 \\
\text { days of } \\
\text { age }\end{array}$ & $\begin{array}{c}28-42 \\
\text { days of } \\
\text { age }\end{array}$ & $\begin{array}{c}1-42 \\
\text { days of age }\end{array}$ \\
\hline \multicolumn{7}{|c|}{ 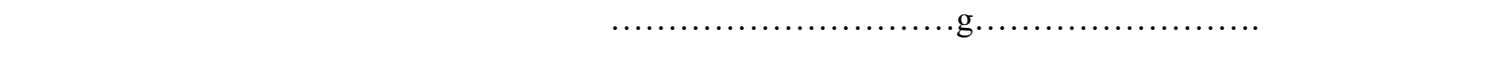 } \\
\hline $\mathrm{T}_{1}$ & $\begin{array}{c}1218.45^{\mathrm{c} 2,3} \\
\pm 20.23\end{array}$ & $\begin{array}{c}1970.19^{d} \\
\pm 17.70\end{array}$ & $\begin{array}{l}751.74^{\mathrm{d}} \\
\pm 10.57\end{array}$ & $\begin{array}{c}1924.98^{\mathrm{d}} \\
\pm 11.95\end{array}$ & $\begin{array}{l}53.79^{c} \\
\pm 0.83\end{array}$ & $\begin{array}{l}46.13^{\mathrm{ab}} \\
\pm 0.73\end{array}$ \\
\hline \multicolumn{7}{|c|}{-20.20} \\
\hline & $\begin{array}{c}1232.23^{\mathrm{ab}} \\
\pm 9.80\end{array}$ & $\begin{array}{l}2027.34^{\mathrm{b}} \\
\pm 12.25\end{array}$ & $\begin{array}{c}795.11^{\mathrm{b}} \\
\pm 9.94\end{array}$ & $\begin{array}{l}1982.53^{\mathrm{b}} \\
\pm 10.25\end{array}$ & $\begin{array}{l}56.79^{\mathrm{ab}} \\
\pm 0.94\end{array}$ & $\begin{array}{l}47.36^{\mathrm{b}} \\
\pm 1.12\end{array}$ \\
\hline \multicolumn{7}{|l|}{$\mathrm{T}_{3}$} \\
\hline & $\begin{array}{c}1220.06^{\mathrm{b}} \\
\pm 16.58\end{array}$ & $\begin{array}{c}1995.42^{\mathrm{c}} \\
\pm 10.16\end{array}$ & $\begin{array}{l}775.36^{\mathrm{c}} \\
\pm 7.53\end{array}$ & $\begin{array}{l}1948.15^{\mathrm{c}} \\
\pm 13.15\end{array}$ & $\begin{array}{l}55.50^{\mathrm{b}} \\
\pm 1.14\end{array}$ & $\begin{array}{l}46.28^{\mathrm{ab}} \\
\pm 1.09\end{array}$ \\
\hline \multicolumn{7}{|l|}{$\mathrm{T}_{4}$} \\
\hline & $\begin{array}{c}1262.50^{\mathrm{a}} \\
\pm 9.49\end{array}$ & $\begin{array}{c}2075.13^{\mathrm{a}} \\
\pm 8.26\end{array}$ & $\begin{array}{c}812.63^{\mathrm{a}} \\
\pm 8.49\end{array}$ & $\begin{array}{c}2029.97^{\mathrm{a}} \\
\pm 10.26\end{array}$ & $\begin{array}{l}58.07^{\mathrm{a}} \\
\pm 1.19\end{array}$ & $\begin{array}{l}50.02^{\mathrm{a}} \\
\pm 1.02\end{array}$ \\
\hline Sig. & $*$ & $*$ & $*$ & $*$ & $*$ & $*$ \\
\hline $\begin{array}{l}\text { control; basal diet } \\
\text { and } T_{4} \text {; basal diet }\end{array}$ & $\begin{array}{l}\text { any supp } \\
\text { tric acid }\end{array}$ & $\begin{array}{l}\text { ntation, } T_{2} \\
\% \text { acetic ac }\end{array}$ & diet $+2 \% c$ & id, $T_{3} ;$ basal d & $d i e t+1 \% a c$ & eticacid \\
\hline
\end{tabular}

The findings are supported with that of (Mustafa et al. (2014); Sultan et al. 2015; Al- Harthi and Attia (2016) who suggested that the inclusion of organic acids (citric acid and acetic acid) in broiler chicks diet significantly enhanced FCR. Organic acids added to feeds should be protected to avoid their dissociation in the crop and in the intestine (high $\mathrm{pH}$ segments), where the bulk of the bacteria population located. The beneficial effect of growth promoter substances on performance is related to a more efficient use of nutrients, which in turn results in an improveing FCR. Similar obsrvations were noticed by Rahman et al. (2018); Sabour et al. (2019) and Omidi et al. (2020). However, Araujo et al. (2018) and Elmi et al. (2020) did not observe differences in FCR of broilers fed diets contained acetic acid and citric acid supplementation during 1- $35 \mathrm{~d}$ and 1- 42 days of age.

Results presented in Table (3) indicated that there were significant differences among treatments in performance index (PI) during the different experimental periods 14, 28 and 42 days of age. Performance index recorded $34.05,29.48,32.87$ and $26.94 \%$ for chicks fed experimental diets $\left(\mathrm{T}_{4} ; 1 \% \mathrm{CA}+0.5 \%\right.$ $\mathrm{AC}), \mathrm{T}_{3}(1 \% \mathrm{AC}), \mathrm{T}_{2}(2 \% \mathrm{CA})$ and control diets $\left(\mathrm{T}_{1}\right)$, respectively at 14 days of age. The highest PI $(72.97 \%)$ was recorded in chicks fed the mixture of organic acid $\left(\mathrm{T}_{4}\right)$ followed by $68.10,66,01 \%$ in groups fed $2 \% \mathrm{CA}\left(\mathrm{T}_{2}\right)$, and $1 \% \mathrm{AC}\left(\mathrm{T}_{3}\right)$, respectively compared to $63.46 \%$ in the control group at 28 days of age. The best PI was obtained with chickens fed the mixture of $1 \%$ citric and $0.5 \%$ acetic acids $(94.75 \%)$, while the lowest PI value was obtained in control group being $78.81 \%$. The positive response on PI by organic acid in early life could be attributed to the decreasing $\mathrm{pH}$ and increasing the proteolytic enzyme activity and nutrient digestability along with bacteriostatic and bactericidal action to the pathogenic bacteria (Papatsiros et al. 2013). 
Table (3): Effect of dietary citric acid, acitic acid or their mixture supplementaltion on average feed intake (FI), feed conversion ratio (FCR) and performance index $(\mathrm{PI}, \%)$ of broilerchicks during experimental periods (Means \pm S.E).

\begin{tabular}{|c|c|c|c|c|c|c|}
\hline \multirow[b]{2}{*}{ Parameters } & \multirow[b]{2}{*}{ Age (days) } & \multicolumn{4}{|c|}{ Dietary treatments $^{1}$} & \multirow[b]{2}{*}{ Sig. } \\
\hline & & $\mathrm{T}_{1}$ & $\mathrm{~T}_{2}$ & $\mathrm{~T}_{3}$ & $\mathrm{~T}_{4}$ & \\
\hline \multirow{4}{*}{$\begin{array}{c}\text { Feed intake } \\
(\mathrm{FI}, \mathrm{g} / \text { chick /day) }\end{array}$} & $1-14$ & $57.87^{\mathrm{a} 2,3} \pm 0.67$ & $54.93^{\mathrm{b}} \pm 0.30$ & $56.35^{\mathrm{a}} \pm 0.35$ & $54.79^{\mathrm{c}} \pm 0.42$ & $*$ \\
\hline & $14-28$ & $95.71^{\mathrm{a}} \pm 0.57$ & $91.14^{\mathrm{c}} \pm 0.59$ & $93.45^{\mathrm{b}} \pm 0.79$ & $90.17^{\mathrm{d}} \pm 0.18$ & $*$ \\
\hline & $28-42$ & $133.16^{\mathrm{a}} \pm 0.49$ & $128.01^{\mathrm{b}} \pm 0.26$ & $132.08^{a} \pm 0.22$ & $125.33^{c} \pm 0.37$ & $*$ \\
\hline & $1-42$ & $95.67^{\mathrm{a}} \pm 0.47$ & $91.45^{\mathrm{c}} \pm 0.43$ & $93.96^{\mathrm{b}} \pm 0.35$ & $90.11^{\mathrm{d}} \pm 0.56$ & $*$ \\
\hline \multirow{4}{*}{$\begin{array}{l}\text { Feed conversion ratio } \\
\text { (FCR,g feed/g gain) }\end{array}$} & $1-14$ & $1.82^{\mathrm{a}} \pm 0.08$ & $1.60^{c} \pm 0.02$ & $1.72^{\mathrm{b}} \pm 0.01$ & $1.57^{\mathrm{d}} \pm 0.03$ & * \\
\hline & $14-28$ & $1.92^{\mathrm{a}} \pm 0.01$ & $1.81^{c} \pm 0.02$ & $1.86^{\mathrm{b}} \pm 0.02$ & $1.73^{\mathrm{d}} \pm 0.01$ & $*$ \\
\hline & $28-42$ & $2.50^{\mathrm{a}} \pm 0.03$ & $2.25^{c} \pm 0.08$ & $2.38^{\mathrm{b}} \pm 0.08$ & $2.19^{\mathrm{d}} \pm 0.08$ & $*$ \\
\hline & $1-42$ & $2.08^{\mathrm{a}} \pm 0.18$ & $1.89^{\mathrm{c}} \pm 0.09$ & $1.99^{b} \pm 0.02$ & $1.83^{\mathrm{d}} \pm 0.02$ & $*$ \\
\hline \multirow{3}{*}{$\begin{array}{l}\text { Performance index } \\
\quad(\mathrm{PI}, \%)\end{array}$} & 14 & $26.94^{\mathrm{d}} \pm 2.90$ & $32.87^{b} \pm 2.20$ & $29.48^{\mathrm{c}} \pm 2.43$ & $34.05^{\mathrm{a} 2,3} \pm 2.20$ & $*$ \\
\hline & 28 & $63.46^{\mathrm{d}} \pm 1.43$ & $68.10^{\mathrm{b}} \pm 2.73$ & $66.01^{\mathrm{c}} \pm 1.73$ & $72.97^{\mathrm{a}} \pm 1.40$ & $*$ \\
\hline & 42 & $78.81^{\mathrm{d}} \pm 3.21$ & $90.13^{b} \pm 2.26$ & $88.84^{\mathrm{c}} \pm 2.74$ & $94.75^{\mathrm{a}} \pm 2.33$ & $*$ \\
\hline
\end{tabular}

${ }^{I} T_{1}$; control; basal diet without any supplementation, $T_{2}$; basal diet $+2 \%$ citric acid, $T_{3}$; basal diet $+1 \%$ acetic acid and $T_{4}$; basal diet $+1 \%$ citric acid $+0.5 \%$ acetic acid.

${ }^{2}$ means $\pm S$. E. of 3 replicates / treatment.

${ }^{3} a, b, c$ and ....etc., means within the same row with each different superscript are significantly differen $(P \leq 0.05)$.

\section{Mortality, Livability and European productive efficiency:}

Experimental results presented in Table 4 showed the effect of dietary citric and acetic acids or their mixture supplementation on mortality, livability and European productive efficiency at 42 days of age. Mortality $\%$ was obtained between 3 and $13 \%$. The lower value of mortality percentage (3.33) was in $\mathrm{T}_{4}$ and the higher mortality percentage was obtained in $\mathrm{T}_{1}$ : control (13.33). Moreover, livability \% was significantly improved (96.67\%) in chicks fed diet supplemented with the mixture of $1 \% \mathrm{CA}+0.5 \% \mathrm{AC}$ followed by chicks fed $1 \% \mathrm{AC}$ and those fed $2 \% \mathrm{CA}$, being 93.33 and $90.00 \%$, respectively compared to $86.67 \%$ in the control group. The same trend was noticed at European productive efficiency which recorded $218.61,192.38,186.31$ and 162.62 for chicks fed $\mathrm{T}_{4}, \mathrm{~T}_{2}, \mathrm{~T}_{3}$ and $\mathrm{T}_{1}$, respectively at 42 days of age (Table 4). In summary, the better livability \% and European productive efficiency (EPE) in organic acid $(\mathrm{CA}+\mathrm{AC})$ addition in broiler diets may be due to the effect of organic acid in controlling pathogenic bacteria or maintaining the health of the GIT (Flamand et al. 2014).

Allahdoa et al. (2018); Adhikari et al. (2020) and Stamilla et al. (2020) observed that overall mortality was lower in organic acid supplementation compared to control groups. Generaly the positive impact of dietary organic acids as citric acid (CA), acetic acid (AC) or their mixture on growth performance may be attributed to: a) A reduction of the $\mathrm{pH}$ values in the feed and digestive tract, serving as a barrier against pathogenic micro - organisms which are sensitive to low $\mathrm{pH}$ values. b) The direct antimicrobial effect. Our results are disagree with the results of (Flamand et al., 2014 and seifi et al., 2015) who reported that there were no significant differences in mortality rate by adding levels of organic acids $(0.5,1,1.5$ and $2 \%$ ) than control group during 22- $42 \mathrm{~d}$. in broiler chickens. 
Table (4): Effect of dietary citric acid, acitic acid or their mixture supplementation on mortality, livability and European productive efficiency of broiler chicks during experimental periods ( Means \pm S.E.).

\begin{tabular}{|c|c|c|c|c|}
\hline \multirow{2}{*}{ Item } & \multicolumn{4}{|c|}{ Dietary treatments ${ }^{1}$} \\
\hline & $\mathrm{T}_{1}$ & $\mathrm{~T}_{2}$ & $\mathrm{~T}_{3}$ & $\mathrm{~T}_{4}$ \\
\hline $\begin{array}{l}\text { Number of birds at the beginning of the } \\
\text { experiment. }\end{array}$ & 30 & 30 & 30 & 30 \\
\hline $\begin{array}{l}\text { Number of birds at the end of the } \\
\text { experiment. }\end{array}$ & 26.00 & 27.00 & 28.00 & 29.00 \\
\hline Final body weight, $(\mathrm{Kg})$. & 1.97 & 2.02 & 1.99 & 2.08 \\
\hline Mortality percentage, $(\%)$. & 13.33 & 10 & 6.67 & 3.33 \\
\hline Livability percentage, $(\%)$. & 86.67 & 90.00 & 93.33 & 96.67 \\
\hline European productive efficiency, $(\text { EPE, } \%)^{2}$ & 162.62 & 192.38 & 186.31 & 218.61 \\
\hline
\end{tabular}

${ }^{I} T_{1}$; control; basal diet without any supplementation, $T_{2}$; basal diet $+2 \%$ citric acid, $T_{3}$; basal diet $+1 \%$ acetic acid and $T_{4}$; basal diet $+1 \%$ citric acid $+0.5 \%$ acetic acid

${ }^{2} \mathrm{EPE}, \%=($ Mean body weight, $\mathrm{Kg} . \times$ livability $\% \times 100) /$ feed conversion $\times$ marketing age, days $)$, cited by Soltan and Kusainova, 2012.

\section{Effect of dietary citric acid and acetic acid supplementation on carcass characteristics and some immune responses parameters of broiler chicks:}

Experimental results of the effect of adding CA, AC or their mixture supplementation to broiler chick diet on carcass characteristics and immune organs parameters at 42 days of age are shown in Tables 5 and 6. At 42 days of age addition of $\mathrm{AC}$ and $\mathrm{CA}$ mixture to broiler chicks significantly increased preslaughter and carcass weight (2243.76 and $1733.70 \mathrm{~g})$ for $\mathrm{T}_{4}(1 \% \mathrm{CA}+0.5 \% \mathrm{AC})$ in comparsion with (2115.40 and 1593.40) $\mathrm{T}_{2}(2 \% \mathrm{CA})$ and (1992.10 and 1517.70g) in $\mathrm{T}_{3}$ (1\% AC) compared to (1944.50 and $1428.00 \mathrm{~g}$ ) in $\mathrm{T}_{1}$, control treatment, respectively. Weight and percentages of liver, gizzard were significantly affected by dietary levels of organic acids, $2 \% \mathrm{CA}, 1 \% \mathrm{AC}$ and their mixture at 42 days of age. The increased dressing yield on dietary organic acids might be due to increasing live weight (Mohammed 2016). The mixture addition of $1 \%$ citric acid with $0.5 \%$ acetic acid resulted in decreasing the level of abdominal fat percentage in carcass $(1.27 \%)$ for group $\mathrm{T}_{4}$ followed by $(1.43,1.49$ and $1.64 \%)$ for $1 \% \mathrm{AC}, 2 \% \mathrm{CA}$ and control groups, respectively at 42 days of age (Table 5).

Table (5): Effect of dietary citric acid, acitic acid or their mixture supplementation on carcass characteristics of broiler chicks at 42 days of age ( Means \pm S. E).

\begin{tabular}{|c|c|c|c|c|c|}
\hline \multirow{2}{*}{ Item } & \multicolumn{4}{|c|}{ Dietary treatment $^{1}$} & \multirow{2}{*}{ Sig. } \\
\hline & $\mathrm{T}_{1}$ & $\mathrm{~T}_{2}$ & $\mathrm{~T}_{3}$ & $\mathrm{~T}_{4}$ & \\
\hline Pre-slaughter weight, g & $1944.50^{c} \pm 19.99$ & $2115.40^{\mathrm{b}} \pm 16.05$ & $1992.10^{c} \pm 4.35$ & $2243.70^{\mathrm{a} 2,3} \pm 22.33$ & * \\
\hline Carcass weight, g. & $1428.00^{\mathrm{d}} \pm 17.84$ & $1593.40^{\mathrm{b}} \pm 11.82$ & $1517.70^{c} \pm 3.18$ & $1733.70^{\mathrm{a}} \pm 17.23$ & $*$ \\
\hline Dressing percentage, $\%$ & $73.40^{\mathrm{d}} \pm 1.67$ & $75.30^{c} \pm 0.12$ & $76.20^{\mathrm{b}} \pm 0.12$ & $77.30^{\mathrm{a}} \pm 0.08$ & $*$ \\
\hline Abdominal fat, $g$ & $31.90^{\mathrm{a}} \pm 0.43$ & $31.50^{\mathrm{b}} \pm 0.65$ & $28.49^{c} \pm 0.45$ & $28.49^{c} \pm 0.39$ & $*$ \\
\hline Abdominal fat, $\%$ & $1.64^{\mathrm{a}} \pm 0.04$ & $1.49^{\mathrm{b}} \pm 0.04$ & $1.43^{c} \pm 0.04$ & $1.27^{\mathrm{d}} \pm 0.04$ & $*$ \\
\hline Liver weight, $\mathrm{g}$ & $42.60^{c} \pm 0.47$ & $55.50^{\mathrm{b}} \pm 0.59$ & $55.50^{\mathrm{b}} \pm 0.42$ & $64.70^{\mathrm{a}} \pm 0.58$ & $*$ \\
\hline Liver, $\%$. & $3.00^{\mathrm{d}} \pm 0.004$ & $3.50^{c} \pm 0.01$ & $3.70^{\mathrm{b}} \pm 0.03$ & $3.70^{\mathrm{a}} \pm 0.004$ & $*$ \\
\hline Gizzard weight, $\mathrm{g}$ & $48.70^{\mathrm{d}} \pm 0.72$ & $61.00^{c} \pm 0.35$ & $65.00^{b} \pm 0.06$ & $72.10^{\mathrm{a}} \pm 0.81$ & $*$ \\
\hline Gizzard $\%$. & $3.40^{\mathrm{d}} \pm 0.02$ & $3.80^{c} \pm 0.01$ & $4.30^{\mathrm{a}} \pm 0.01$ & $4.20^{\mathrm{b}} \pm 0.01$ & $*$ \\
\hline Heart weight, g & $8.40^{c} \pm 0.09$ & $9.10^{\mathrm{b}} \pm 0.21$ & $7.00^{d} \pm 0.15$ & $10.10^{\mathrm{a}} \pm 0.06$ & $*$ \\
\hline Heart, $\%$. & $0.60 \pm 0.008$ & $0.60 \pm 0.01$ & $0.50 \pm 0.01$ & $0.60 \pm 0.01$ & NS \\
\hline Giblets weight, $\mathrm{g}$ & $99.70^{c} \pm 1.23$ & $125.5^{\mathrm{b}} \pm 1.09$ & $127.5^{\mathrm{b}} \pm 0.34$ & $146.8^{\mathrm{a}} \pm 1.34$ & $*$ \\
\hline Giblets \% & $6.96^{c} \pm 0.02$ & $7.88^{b} \pm 0.01$ & $8.40^{a} \pm 0.03$ & $8.47^{\mathrm{a}} \pm 0.01$ & $*$ \\
\hline
\end{tabular}

${ }^{I} T_{1}$; control; basal diet without any supplementation, $T_{2}$; basal diet $+2 \%$ citric acid, $T_{3}$; basal diet $+1 \%$ acetic acid and $T_{4}$; asal diet $+1 \%$ citric acid $+0.5 \%$ acetic acid.

${ }^{2}$ means $\pm S$. E. of 3 replicates / treatment.

${ }^{3} a, b, c$ and ....etc. means within the same row with each different superscript are significantly different $(P \leq 0.05)$.

The present results indicated that organic acids used for $42 \mathrm{~d}$ maintained sufficient undissociated acid molecules, which appeared to produce bacteriostatic or bactericidal effect leading to better carcass yield 
and lower abdominal fat than diets without organic acids. The reduction in abdominal fat might be supplemented dietary acidification in broiler diets and has a role in lipid metabolism (Leeson et al., 2005). Also, The results are conincides with Youssef et al. (2017) who indicated that chicks fed diet supplemented with $\mathrm{CA}$ or AC had significantly increased carcass yields. Also, Sharifuzzaman et al. (2020) reported that the highest dressing percentage $(69 \%)$ was noticed where $0.75 \%$ citric acid was added to diet. While, Lakshmi and Sunder (2013) who observed that abdominal fat percent was lower in broiler fed 1 and $2 \%$ citric acid up to 42 days of age. On contrary, Rehman et al. (2016), Saleem et al. (2016), Ali et al. (2019) and Sabour et al. (2019) observed that there was no significant differences in dressing percentage by having diets supplemented with citric and / or acetic acid.

Data presented in Table (6) showed the effect of dietary 2\% CA, 1\% AC or their mixture on some immune organs of relative weights and percentage (thyme, spleen and bursa of fabricus) at the end of experiment ( 42 days of age broiler chicks). Data exhibited the relative weights and percent of thymus and bursa increased by addition of single citric or acetic acids or their mixture. The highest values were reported for $(1 \% \mathrm{CA}+0.5 \% \mathrm{AC}, \mathrm{T} 4)$, being $(3.99 \mathrm{~g} \%$ and $0.23 \%)$ of thymus $\%$ and $(3.34 \mathrm{~g}$ and $0.19 \%)$ for bursa $\%$, respectively at $42 \mathrm{~d}$ in comparsion with other treatments. While, percentages of spleen did not significantly differ between all treatments. The improvement in immunity might be due to the inhibitory effects of these OA on gut pathogens. In addition, OA supplementation caused hyper - thyroidism and peripheral conversion of $\mathrm{T}_{4}-\mathrm{T}_{3}$ which indicate that these birds had better immune competence and bursa growth (Abdel Fattah et al., 2008). The major constituents of the avian immune system are the lymphoid organs as bursa, spleen and thymus had mild to moderate hyperplasia of their lymphoid follicles which indicate that the immune response was increased (Attia et al. 2018).

The relative increase in weight organs of bursa, spleen and two primary lymphoid organs were conciderd as an indication of immunological advances. The establishment of immune response associated with dietary acidification could be on account for their inhibitory effects against the pathogenic microorganisms throughout the GI tract providing scope for improved nutrient absorption. The higher immunity due to organic acids can also be attributed to higher nutrient efficiency, which might have triggened immunogenic cells to record higher immune response (Ram Rao et al., 2004). The results of the peresnt experiment reported herein were also in agreement with those of Mohammadi and Khosravinia (2015) and Attia et al. (2018) who noted that the use of organic acid leads to an increase in the number of contributing cells in immune and then increase the bursa of fabricius weight. However, the results of Saleem et al. (2016) and Allahdoa et al. (2018) disagree with of the peresnt study

Table (6): Effect of dietary citric acid, acitic acid or their mixture supplementation on immune organs of broiler chicks at 42 days of age ( Means \pm S. E).

\begin{tabular}{|c|c|c|c|c|c|}
\hline \multirow{2}{*}{ Item } & \multicolumn{4}{|c|}{ Dietary treatment $^{1}$} & \multirow[t]{2}{*}{ Sig. } \\
\hline & $\mathrm{T}_{1}$ & $\mathrm{~T}_{2}$ & $\mathrm{~T}_{3}$ & $\mathrm{~T}_{4}$ & \\
\hline Thymus weight, g. & $2.17^{\mathrm{d}} \pm 0.06$ & $3.03^{c} \pm 0.15$ & $2.92^{b} \pm 0.12$ & $3.99^{\mathrm{a} 2,3} \pm 0.17$ & $*$ \\
\hline Thymus, \%. & $0.15^{\mathrm{c}} \pm 0.005$ & $0.19^{b} \pm 0.02$ & $0.19^{b} \pm 0.01$ & $0.23^{a} \pm 0.01$ & $*$ \\
\hline Spleen weight, g. & $1.15^{\mathrm{d}} \pm 0.13$ & $1.59^{\mathrm{b}} \pm 0.06$ & $1.36^{\mathrm{c}} \pm 0.12$ & $2.08^{a} \pm 0.16$ & $*$ \\
\hline Spleen, $\%$. & $0.08 \pm 0.01$ & $0.10 \pm 0.004$ & $0.09 \pm 0.01$ & $0.12 \pm 0.01$ & NS \\
\hline Bursa, g. & $2.04^{\mathrm{d}} \pm 0.15$ & $2.75^{\mathrm{c}} \pm 0.15$ & $2.92^{b} \pm 0.12$ & $3.34^{\mathrm{a}} \pm 0.15$ & $*$ \\
\hline Bursa, \%. & $0.14^{\mathrm{c}} \pm 0.01$ & $0.17^{\mathrm{b}} \pm 0.01$ & $0.19^{\mathrm{a}} \pm 0.01$ & $0.19^{\mathrm{a}} \pm 0.01$ & $*$ \\
\hline
\end{tabular}

\section{Effect of dietary citric acid and acetic acid supplementation on some serum biochemical parameters of broiler chicks:}

Data concerning the effect of citric and acetic acids or their mixture as a diet supplemetation on blood serum constitunets at 42 days are shown in Table 7 . The mixture of citric acid and acetic acid $(1 \% \mathrm{CA}+$ $\left.0.5 \% \mathrm{AC} ; \mathrm{T}_{4}\right)$ significantly $(\mathrm{P} \leq 0.05)$ improved total protein, albumin, globulin and $\mathrm{A} / \mathrm{G}$ ratio compared to the control group. Globulin is a source of antibody production, so its level in the serum is a good indicator of immune responses and conseqantly better disease resistance (Griminger and Scances 1986). Also, Ghazalah et al. (2011) noticed a higher level of globulin in serum blood concentaration which used 
as an indicator for measuring immunity response by addition of organic acids, suggesting that the improvement in bird immunity could be related to the inhibitory effects of organic acids on gut system pathogenes and enhancing the density of the lymphocytes in the lymphoid organs, enhancing the non specific immunity (Haque et al., 2010). In this study, the concentration of serum blood creatinine was not significantly $(\mathrm{P} \leq 0.05)$ differe between all dietary supplemented treatments compared to $\mathrm{T}_{1}$, (unsupplemented) during 42 days of age. Also, the concentration of blood glucose was significantly ( $\mathrm{P} \leq$ 0.05 ) differences by organic acid (CA and AC or their mixture) during 42 days of age. The peresnt results showed that broiler chicks fed diets contained CA and AC or their mixture had significantly lower serum total lipids and cholesterol. Meanwhile, broiler chicks fed diet containing a mixture of CA + AC showed the lowest total lipidsm(TL) and total cholesterol (TCH); being 430.27 and $133.11 \mathrm{mg} / \mathrm{dl}$ for $\mathrm{T}_{4 ;}(1 \%$ $\mathrm{CA}+0.5 \% \mathrm{AC}$ ), respectively, when compared to the control treatment (550.39 and $159.13 \mathrm{mg} / \mathrm{dl}$ ) for TL and $\mathrm{TCH}$, respectively.

The decrease in blood lipid profile may be due to the beneficial role of organic acids in decreasing the microbial intracellular $\mathrm{pH}$. Thus, inhibits the action of important microbial enzymes and forces the bacterial cell to use energy to release the acid protons, lead into an intracellular accumulation of acid anions (Young and Foegeding, 1993). Organic acid treatments insignificantly influenced each of ALT and AST compared to the control treatment at 42 days of age, chicks fed diet supplemented with $2 \% \mathrm{CA}\left(\mathrm{T}_{2}\right)$, $1 \% \mathrm{AC}\left(\mathrm{T}_{3}\right)$ and $1 \% \mathrm{CA}+0.5 \% \mathrm{AC}\left(\mathrm{T}_{4}\right)$ had the lowest value of ALT $(14.78,14.81$ and 14.35), respectively in comparsion with control treatment (15.14), while AST enzyme was insignificantly influenced by dietary treatments $(\mathrm{P}>0.05)$ at 42 days of age (Table 7). This result is harmony with those of Capcarova et al. (2014); Rahman et al. (2018) and Ali et al. (2019) who report that total protein, globulin and $\mathrm{A} / \mathrm{G}$ ratio were $(\mathrm{P} \leq 0.05)$ higher in birds fed diets supplemented with single citric and acetic acids or their mixture supplementation in broiler diets.

Where, Abdel Razek et al. (2016) and Mirderikvandi et al. (2019) reported that total cholesterol was significantly $(\mathrm{P}<0.05)$ decreased in citric acid supplementation of broiler chickens at 5 weeks of age. Other studies noticed negative effects on total protein, globulin, glucose, albumin and A / G ratio in cornbased diets supplemented with organic acids of Mohammadi and Khosravinia (2015) and Mirderikvandi et al. (2019). Generally, serum biochemical constituents reflect the health, nutrition, climate and management conditions which the animals are submitted (Minafara et al., 2010). The levels of biochemical parameters in the blood can be used as an indicator of the productive performance of the birds and of metabolic disease (Rotava et al., 2008). Measurements of AST and ALT activities are indicatives of liver damage in broiler chicks and its therefore available tool for determination of a safe inclusion rate for feed additives.

Table (7): Effect of dietary citric acid, acitic acid or their mixture supplementation on some blood serum contituents of broiler chicks at 42 days of age ( Means \pm S.E.).

\begin{tabular}{|c|c|c|c|c|c|}
\hline \multirow[b]{2}{*}{ Item } & \multicolumn{4}{|c|}{ Dietary treatment ${ }^{1}$} & \multirow[b]{2}{*}{ Sig. } \\
\hline & $\mathrm{T} 1$ & $\mathrm{~T}_{2}$ & $\mathrm{~T}_{3}$ & $\mathrm{~T}_{4}$ & \\
\hline Total protein, g / dI. & $4.38^{\mathrm{d}} \pm 0.006$ & $4.43^{c} \pm 0.011$ & $4.51^{b} \pm 0.006$ & $4.56^{\mathrm{a} 2,3} \pm 0.006$ & $*$ \\
\hline Albumen (A), g / dI. & $2.40^{\mathrm{d}} \pm 0.006$ & $2.47^{\mathrm{c}} \pm 0.006$ & $2.52^{\mathrm{b}} \pm 0.012$ & $2.58^{\mathrm{a}} \pm 0.012$ & $*$ \\
\hline Globulin (G), g / dI. & $1.94^{\mathrm{c}} \pm 0.006$ & $1.96^{\mathrm{b}} \pm 0.006$ & $1.99^{\mathrm{a}} \pm 0.006$ & $1.98^{\mathrm{a}} \pm 0.006$ & $*$ \\
\hline A / G ratio & $1.24^{\mathrm{d}} \pm 0.005$ & $1.26^{\mathrm{c}} \pm 0.001$ & $1.27^{\mathrm{b}} \pm 0.003$ & $1.30^{\mathrm{a}} \pm 0.002$ & $*$ \\
\hline Creatinine, $\mathrm{mg}$ / dI. & $1.43 \pm 0.006$ & $1.42 \pm 0.006$ & $1.40 \pm 0.001$ & $1.42 \pm 0.001$ & NS \\
\hline Total lipids, mg / dI. & $550.39^{\mathrm{a}} \pm 0.57$ & $448.13^{\mathrm{b}} \pm 0.02$ & $435.88^{\mathrm{c}} \pm 0.58$ & $430.27^{\mathrm{d}} \pm 0.58$ & $*$ \\
\hline Total cholesterol, mg / dI. & $159.13^{\mathrm{a}} \pm 0.58$ & $149.00^{\mathrm{b}} \pm 0.57$ & $137.18^{c} \pm 0.33$ & $133.11^{\mathrm{d}} \pm 0.01$ & $*$ \\
\hline Glucose, mg / dI. & $234.07^{\mathrm{a}} \pm 0.02$ & $231.66^{\mathrm{b}} \pm 0.57$ & $232.91^{\mathrm{c}} \pm 0.58$ & $227.11^{\mathrm{d}} \pm 0.59$ & $*$ \\
\hline ALT, U / L. & $15.14^{\mathrm{a}} \pm 0.059$ & $14.78^{c} \pm 0.058$ & $14.81^{\mathrm{b}} \pm 0.059$ & $14.35^{\mathrm{d}} \pm 0.058$ & $*$ \\
\hline AST, U / L. & $42.11 \pm 0.59$ & $42.03 \pm 0.57$ & $42.14 \pm 0.57$ & $42.03 \pm 0.57$ & NS \\
\hline \multicolumn{6}{|c|}{$\begin{array}{l}{ }^{1} T_{1} ; \text { control; basal diet without any supplementation, } T_{2} \text {; basal diet }+2 \% \text { citric acid, } T_{3} ; \text { basal diet }+1 \% \\
\text { acetic acid and } T_{4} ; \text { basal diet }+1 \% \text { citric acid }+0.5 \% \text { acetic aci }\end{array}$} \\
\hline
\end{tabular}

Effect of dietary citric acid, acitic acid or their mixture supplementation on intestinal morphological 


\section{parameters of broiler chicks:}

The average villus height, width , crypt depth, muscular thickness and villi height: crypt depth of duodenum, jejunum and illum of broiler chickens measurments at 42 days of age are presented in Tables $(8,9$ and 10) and illustrated in Figures (1, 2 and 3). Data showed significant increase $(\mathrm{P} \leq 0.05)$ in villi hieght of duodenum, jejnum and illum with the addition of citric and acetic acids mixture $(1 \% \mathrm{CA}+0.5 \%$ $\left.\mathrm{AC}, \mathrm{T}_{4}\right)$; being $2173.99,1453.94$ and $970.07 \mu \mathrm{m}$ as comparion with the other treatments ( 1741.36, 1339.26 and $\left.1028.18 \mu \mathrm{m}, \mathrm{T}_{2}\right),\left(1783.06,1101.42\right.$ and $\left.784.07 \mu \mathrm{m}, \mathrm{T}_{3}\right)$ and in the control $\left(\mathrm{T}_{1}\right)$ group were $1485.17,1079.76$ and $718.09 \mu \mathrm{m}$, respectively. The increase in villus height of the different segments of the small intestine epithelium play key roles in the digestion, absorption and assimilation of nutrients (Wang and Peng, 2008). Organic acidifiers especially acetic acid reduce the growth of many pathogenic or non- pathogenic intestinal bacteria, therefore, reduce intestinal colonization and reduce infectious processes, ultimately decrease inflammatory processes at the intestinal muscosa, which increase villius height, function of secretion, digestion and absorption of nutrients can be appropriately performed by the muscosa (Loddi et al., 2004). Also, Pelicano et al. (2011) reported that increased villius heights in duodenum and jejunum with most of the organic acids reduces the growth of many pathogenic or non pathogenic intestinal bacteria, decreasing the intestinal colonization and infectious processes, ultimately decreasing the inflammatory reactions at the intestinal muscosa, which increases the villius height, the functions of secretion, digestion and absorption of nutrients by the muscosa.

Table (8): Effect of dietary citric acid, acitic acid or their mixture supplementation on the intestinal morphology (duodenum) of broiler chicks at 42 days of age ( Means \pm S.E.).

\begin{tabular}{|c|c|c|c|c|c|}
\hline \multirow{2}{*}{ Histological parameter } & \multicolumn{4}{|c|}{ Dietary treatment ${ }^{1}$} & \multirow{2}{*}{ Sig. } \\
\hline & $\mathrm{T}_{1}$ & $\mathrm{~T}_{2}$ & $\mathrm{~T}_{3}$ & $\mathrm{~T}_{4}$ & \\
\hline Villi height, $\mu \mathrm{m}$. & $1485.17^{\mathrm{c}} \pm 13.58$ & $1741.36^{\mathrm{b}} \pm 55.37$ & $1783.06^{\mathrm{b}} \pm 41.49$ & $2173.99^{a, 2,3} \pm 17.84$ & $*$ \\
\hline Villi width, $\mu \mathrm{m}$. & $156.32^{\mathrm{d}} \pm 10.55$ & $241.09^{\mathrm{b}} \pm 9.31$ & $198.85^{\mathrm{c}} \pm 5.68$ & $313.10^{\mathrm{a}} \pm 15.83$ & $*$ \\
\hline Crypt depth, $\mu \mathrm{m}$. & $140.85^{\mathrm{c}} \pm 4.55$ & $266.37^{\mathrm{a}} \pm 21.42$ & $195.87^{\mathrm{b}} \pm 5.07$ & $261.94^{\mathrm{a}} \pm 13.44$ & $*$ \\
\hline Muscular thickness, $\mu \mathrm{m}$ & $220.44^{\mathrm{d}} \pm 3.06$ & $327.94^{\mathrm{a}} \pm 13.85$ & $264.37^{c} \pm 4.12$ & $293.84^{\mathrm{a}} \pm 12.68$ & $*$ \\
\hline Villi height / Crypt depth & $9.69^{a} \pm 0.58$ & $7.29^{c} \pm 0.44$ & $9.03^{\mathrm{b}} \pm 0.44$ & $7.04^{c} \pm 0.39$ & $*$ \\
\hline
\end{tabular}

${ }^{1} T_{1}$; control; basal diet without any supplementation,$T_{2}$; basal diet $+2 \%$ citric acid, $T_{3} ;$ basal diet $+1 \%$ acetic acid and $T_{4}$; basal diet $+1 \%$ citric acid $+0.5 \%$ acetic acid.

${ }^{2}$ means $\pm S$. E. of 3 replicates / treatment.

${ }^{3} a, b, c$ and ....etc: means within the same row with each different superscript are significantly different $(P \leq 0.05)$.

Villi intestine width values being; 313.10, 217.74 and $213.87 \mu \mathrm{m}$ for $\mathrm{T}_{4}$ of duodenum, jejnum and ileum compared to other treatments which were $\left(241.09,207.94\right.$ and $\left.177.52 \mu \mathrm{m}, \mathrm{T}_{2}\right)$ and $(198.85$, 183.67 and $169.44 \mu \mathrm{m}, \mathrm{T}_{3)}$ and for control group were (156.32, 143,02 and 132.15 $\left.\mu \mathrm{m}\right)$, respectively. Also, crypt depth and muscular thickness of duodenum, jejnum and ileum of broiler chicks measured at 42 days of age and presented in Tables 8, 9 and 10 and illusterated in Figures (1,2 and 3). Muscularis thickness were increased in all segments of small intestine by the addition of citric acid, acetic acid or their mixture compared to the control group. The villus crypt considered as the villus factory, deeper crypts indicate fast tissue turn over to permit renewal of the villus as needed in response to normal slougring or inflammation from pathogens or their toxins and high demands for tissue (Yason et al., 1987).

Increases in the $\mathrm{VH}$ and $\mathrm{VH}$ to $\mathrm{CD}$ ratio directly correlated with increased epithelial cell turnover and longer villi are associated with activated cell mitosis (Awad et al., 2009). These results agreed with those of Rehman et al.( 2016); Allahdoa et al. (2018); Sabour et al. (2019) and Stamilla et al.(2020) who showed that supplementaion of dietary organic acid had significantly effects in small intestine histology. On the other hands, Mohammadagheni et al. (2016) and Attia et al. (2018) found no significant effects of dietary organic acids on muscular thickness of small intestine of broiler chicks. 
Table (9): Effect of dietary citric acid, acitic acid or their mixture supplementation on the intestinal Morphology (Jejunum ) of broiler chicks at 42 days of age ( Means \pm S.E.).

\begin{tabular}{|c|c|c|c|c|c|}
\hline \multirow[t]{2}{*}{ Histologicalparameter } & \multicolumn{4}{|c|}{ Dietary treatment ${ }^{1}$} & \multirow[t]{2}{*}{ Sig. } \\
\hline & $\mathrm{T}_{1}$ & $\mathrm{~T}_{2}$ & $\mathrm{~T}_{3}$ & $\mathrm{~T}_{4}$ & \\
\hline Villi height, $\mu \mathrm{m}$. & $1079.76^{c} \pm 15.57$ & $1339.26^{\mathrm{b}} \pm 8.93$ & $1101.42^{c} \pm 20.71$ & $1453.94^{\mathrm{a} 2,3} \pm 35.25$ & $*$ \\
\hline Villi width, $\mu \mathrm{m}$. & $143.02^{c} \pm 6.47$ & $207.94^{\mathrm{a}} \pm 9.67$ & $183.67^{\mathrm{b}} \pm 11.52$ & $217.74^{\mathrm{a}} \pm 5.16$ & $*$ \\
\hline Crypt depth, $\mu \mathrm{m}$. & $175.69^{\mathrm{b}} \pm 4.75$ & $193.36^{\mathrm{b}} \pm 7.67$ & $188.15^{\mathrm{b}} \pm 1.24$ & $240.26^{\mathrm{a}} \pm 11.46$ & $*$ \\
\hline Muscular thickness, $\mu \mathrm{m}$ & $255.34^{\mathrm{b}} \pm 10.65$ & $237.65^{\mathrm{b}} \pm 11.91$ & $282.48^{a} \pm 4.31$ & $238.08^{\mathrm{b}} \pm 3.25$ & $*$ \\
\hline Villi height / Crypt depth & $7.66^{\mathrm{a}} \pm 0.41$ & $6.51^{\mathrm{b}} \pm 0.32$ & $6.11^{\mathrm{b}} \pm 0.38$ & $6.71^{\mathrm{ab}} \pm 0.26$ & $*$ \\
\hline
\end{tabular}

Table (10): Effect of dietary citric acid, acitic acid or their mixture supplementation on the intestinal morphology (Ileum ) of broiler chicks at 42 days of age ( Means \pm S.E.).

\begin{tabular}{|c|c|c|c|c|c|}
\hline \multirow[b]{2}{*}{ Histologicalparameter } & \multicolumn{5}{|c|}{ Dietary treatment ${ }^{1}$} \\
\hline & $\mathrm{T}_{1}$ & $\mathrm{~T}_{2}$ & $\mathrm{~T}_{3}$ & $\mathrm{~T}_{4}$ & Sig. \\
\hline Villi height, $\mu \mathrm{m}$. & $718.09^{\mathrm{b}} \pm 5.56$ & $1028.18^{\mathrm{a}} \pm 50.40$ & $784.07^{\mathrm{b}} \pm 22.80$ & $970.07^{\mathrm{a} 2,3} \pm 11.46$ & $*$ \\
\hline Villi width, $\mu \mathrm{m}$. & $132.15^{\mathrm{c}} \pm 4.86$ & $177.52^{\mathrm{ab}} \pm 12.81$ & $169.44^{\mathrm{b}} \pm 12.26$ & $213.87^{\mathrm{a}} \pm 15.56$ & $*$ \\
\hline Crypt depth, $\mu \mathrm{m}$. & $126.43^{\mathrm{c}} \pm 9.17$ & $170.56^{\mathrm{b}} \pm 8.50$ & $142.29^{\mathrm{bc}} \pm 9.70$ & $208.66^{\mathrm{a}} \pm 12.54$ & $*$ \\
\hline Muscular thickness, $\mu \mathrm{m}$. & $214.25^{\mathrm{c}} \pm 2.73$ & $261.10^{\mathrm{b}} \pm 11.31$ & $249.57^{\mathrm{b}} \pm 1.56$ & $287.03^{\mathrm{a}} \pm 8.45$ & $*$ \\
\hline Villi height / Crypt depth & $5.47^{\mathrm{a}} \pm 0.21$ & $5.95^{\mathrm{a}} \pm 0.50$ & $4.79^{\mathrm{a}} \pm 0.46$ & $4.70^{\mathrm{a}} \pm 0.36$ & $*$ \\
\hline
\end{tabular}



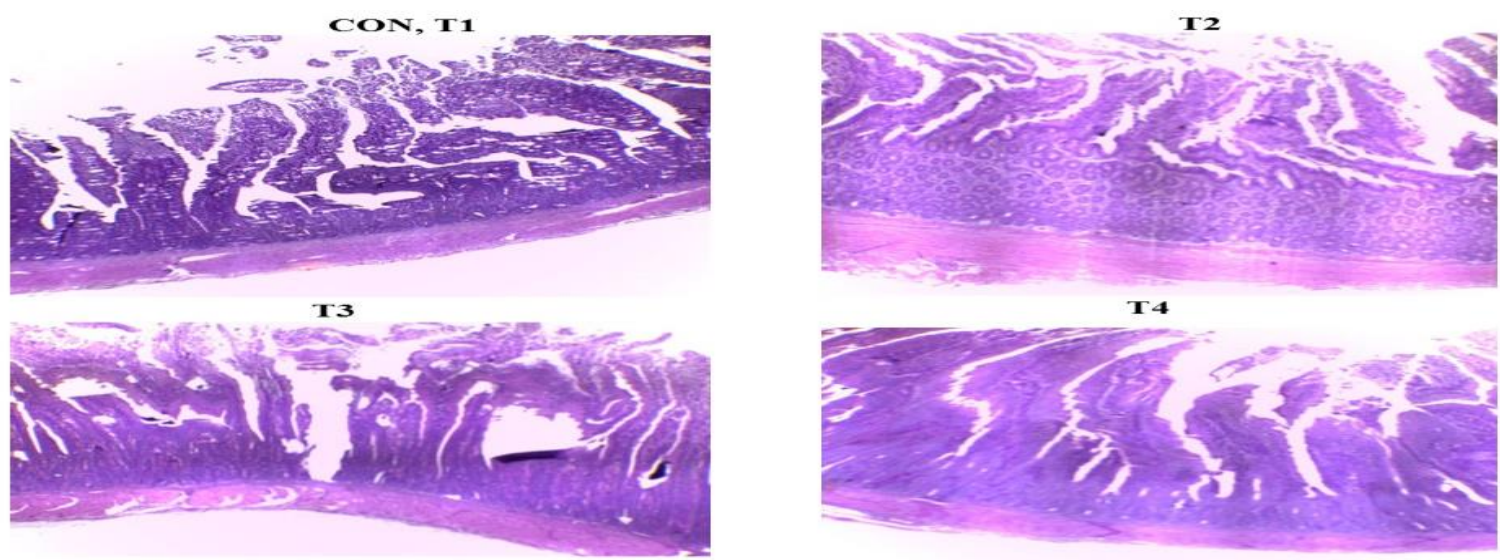

Figure (1): Photomicrographs of intestinal villi from the duodenum of broiler chicks on 42 days of age in $T_{1}$, control, basal Diet without supplementation; $\mathrm{T}_{2}$; basal diet $+2 \%$ citric acid; $\mathrm{T}_{3}$; basal diet+ $1 \%$ acetic acid and $\mathrm{T}_{4}$; basal diet $+1 \%$ cetric $+0.5 \%$ acetic acids.
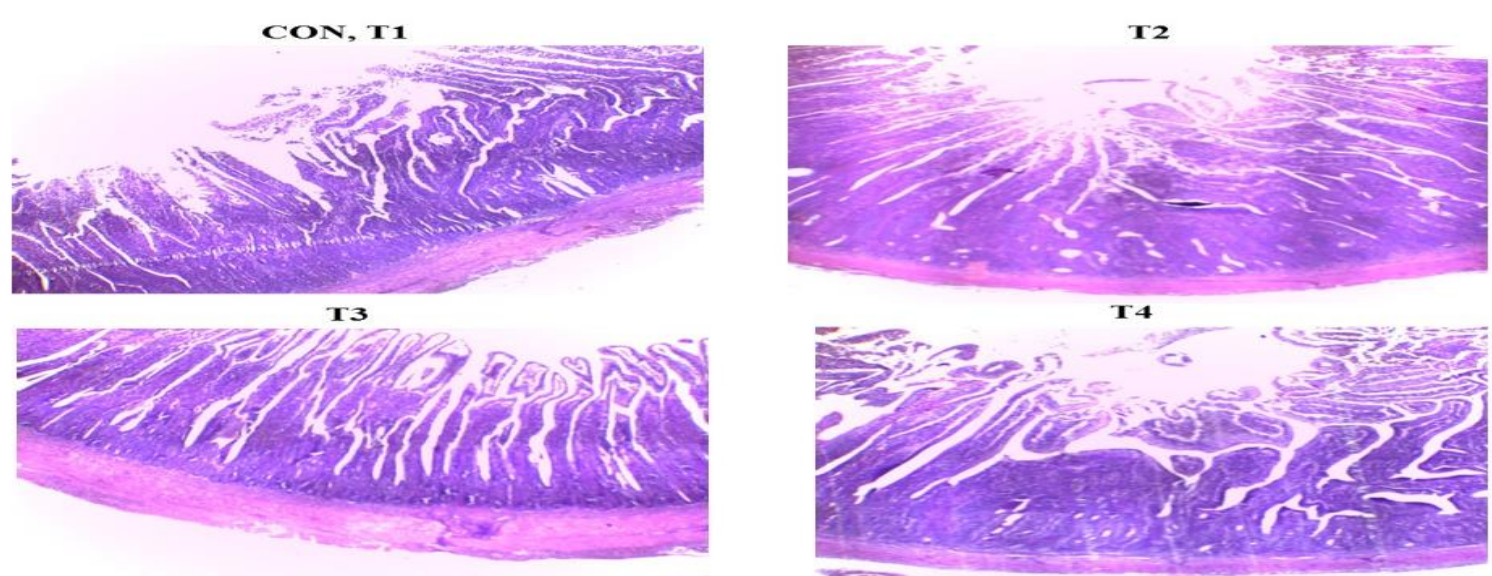

Figure (2): Photomicrographs of intestinal villi from the jujunum of broiler chicks on 42 days of age in $\mathrm{T}_{1}$, control, basal dietwithout supplementation; $\mathrm{T}_{2}$; basal diet $+2 \%$ citric acid; $\mathrm{T}_{3}$; basal diet $+1 \%$ acetic acid and $\mathrm{T}_{4}$; basal diet $+1 \%$ cetric $+0.5 \%$ acetic acids.

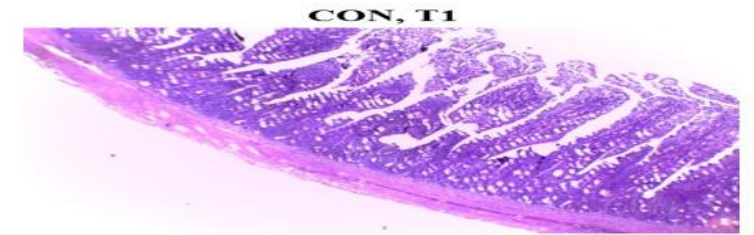

T3

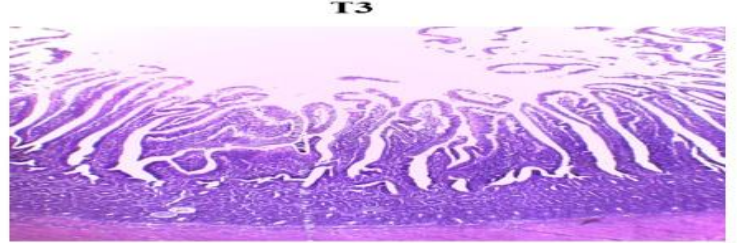

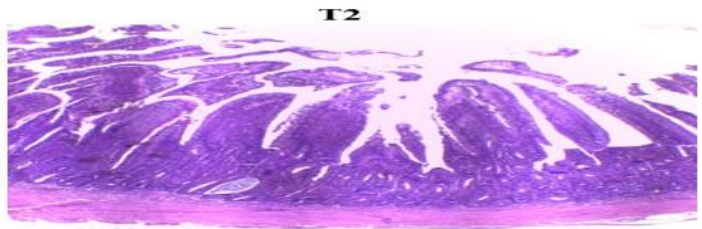

T4

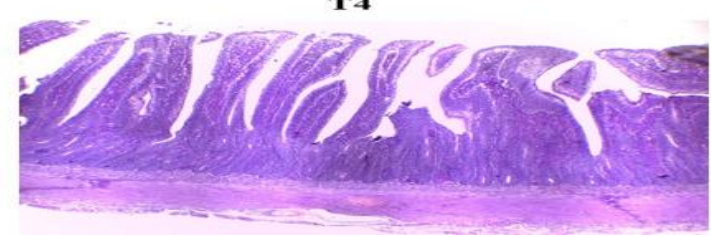

Figure (3): Photomicrographs of intestinal villi from the ileum of broiler chicks on 42 days of age in $\mathrm{T}_{1}$, control, basal diet without supplementation; $T_{2}$; basal diet $+2 \%$ citric acid; $T_{3}$; basal diet $+1 \%$ acetic acid and $\mathrm{T}_{4}$; basal diet $+1 \%$ cetric $+0.5 \%$ acetic acids. 
Effect of dietary citric acid and acetic acid or their mixture supplementation on economic efficiency of broiler chickens:

Data partaining to dietary citric, acetic acids or their mixture supplementation on the relative economical efficiency (REE) are presented in Table (11). In comparsion with the control treatment (100\%), the supplementation of citric and acetic mixture improved REE by $20.72 \%$ for $\mathrm{T}_{4}$ which was supplemented with $(1 \% \mathrm{CA}+0.5 \% \mathrm{AC})$. This may be due to better feed conversion obtained in chicks received the experimental diets. The low values of economical efficiency were obtained for chicks fed diet supplemented with $1 \% \mathrm{AC}\left(\mathrm{T}_{3}\right)$ and $2 \% \mathrm{CA}\left(\mathrm{T}_{2}\right)$, respectively compared to $\mathrm{T}_{4}(1 \% \mathrm{CA}+0.5 \% \mathrm{AC})$ but higher than the control group. This may be due to the increase in the price of acetic acid in the markets. Abdel Fattah et al. (2008) observed that the economic and relative economic efficiency were increased by using citric and acetic acids at ( 1.5 and $3 \%$ ) levels. Ghazalah et al. (2011) found that $0.25 \%$ $\mathrm{AC}$ and 3\% CA supplementation gave the best value of European economic efficiency compared to the control group at 42 days of age. On the other hand, Mirderikvandi et al. (2019) showed that acidified diet (20 mg acetic acid / kg diet) significantly reduced economic efficiency of birds by about $16.77 \%$. Also, Omidi et al. (2020) indicated that acetic acid supplementation to diet decreased economic efficiency by 40 units compared to control birds during 14 to 42 days of age.

Table (11): Effect of dietary citric acid, acitic acid or their mixture supplementation on economic effeciency of broiler chicks during experimental period.

\begin{tabular}{|c|c|c|c|c|}
\hline \multirow[b]{2}{*}{ Item } & \multicolumn{4}{|c|}{ Dietary treatment ${ }^{1}$} \\
\hline & $\mathrm{T}_{1}$ & $\mathrm{~T}_{2}$ & $\mathrm{~T}_{3}$ & $\mathrm{~T}_{4}$ \\
\hline Initial body weight, $\mathrm{g}$. & 45.21 & 45.17 & 45.24 & 45.17 \\
\hline Final body weight, $\mathrm{kg}$. & 1.97 & 2.02 & 1.99 & 2.08 \\
\hline Body weight gain, $\mathrm{kg}$. & 1.92 & 1.97 & 1.94 & 2.03 \\
\hline Total revenue ${ }^{2}$, L.E. & 61.44 & 63.04 & 62.08 & 64.96 \\
\hline Feed intake, kg. & 4.02 & 3.84 & 3.95 & 3.78 \\
\hline Price of one $\mathrm{kg}$ feed, L.E. & 7.25 & 7.30 & 7.36 & 7.34 \\
\hline Feed cost, L.E. & 29.15 & 28.03 & 29.07 & 27.75 \\
\hline Net revenue $^{3}$, L.E. & 32.29 & 35.01 & 33.01 & 37.21 \\
\hline Economical efficiency ${ }^{4}$. & 1.11 & 1.25 & 1.14 & 1.34 \\
\hline Relative economic efficiency, $\%$. & 100 & 112.61 & 102.70 & 120.72 \\
\hline \multicolumn{5}{|c|}{$\begin{array}{l}{ }^{2} \text { Total revenue }=\text { live body weight gain } \times \text { marketing price }(32 \text { L.E. according to pricices in June, 2018). } \\
{ }^{3} \text { Net revenue }=\text { Total revenue }- \text { Feed cost. }\end{array}$} \\
\hline
\end{tabular}

\section{CONCLUSION}

In general, based on the obtained experimental results reported herein and from the nutritional and economical point of view, there are some beneficial effects of using mixture of citric acid and acetic acid $(1 \%$ citric acid $+0.5 \%$ acetic acid ) to broiler (Arbor Acres) diets showed the best productive performance, carcass characteristics, some serum componterty, some histological parameters and better economic efficiency without any adverse effects on health under our local environmental conditions

\section{REFERENCES}

Abdel Fattah, S. A.; M. H. EL-Sanhoury; N. M. EL- Menday and F. Abdel - Azeem (2008). Thyroid activity, some blood constituents, organs morphology and performance of broiler chicks fed supplemental organic acids. International Journal of Poultry Science, 7 (3): 215-222. ISSN 16828356, (C)Asian network for scientific information.

Abdel Razek, H. A. M.; S. M. M. Abuzead; S. A. Ali; H. M. A. El- Genaidy and S. A. Abdel-Hafez (2016). Effect of citric and acetic acid water acidification on broiler's performance with respect to 
thyroid hormonlevels. Advances in Animal and Veterinary Science, Volume 4- Issues- Page 271: 278.

Adhikari, P.; S. Yadav; D. E. Cosby; N. A. Cox; J. A. Jendza and W. K. Kim (2020). Effect of organic acid mixture on growth performance and salmonella typhimurium colonization in broiler chickens. Poultry Science. https://doi.org/10.1016/j.psj.2019.12.037.

Adil, S.; T. Banday; G. A. Bhat and M. Rehman (2010). Effect of dietary supplementation of organic acids on performance, intestinal histomorphology, and serum biochemistry of broiler chicken. Veterinary. Medicine International. Volume, Article ID 479485, 7 pages, doi: 10. 4061/ 479485.

Al-Harthi, M. A. and Y. A. Attia (2016). Effect of citric acid on the nutritive value of olive cake in broiler diets. European Poultry Science. Volume 80, ISSN 1612- 9199@ Veriage Eugen Ulmer, stuttgant. Dol: 10: 1399/eps.153: 167.

Ali, M. N.; A. H. Waly; H. H. Habib; H. M. A. El- Komy and H. A. Abdel Magid (2019). Improve the utilization of broiler low protein diets using threonine, citric acid and sulphate. Egyptian Poultry Sience Journal. 39(IV): 881-894. http://www.epsj.journals.ekb.eg/.

Allahdoa, P.; J. Ghodraty.; H. Zarghi; Z. Saadatfar; H. Kermanshahi and M. Reza (2018). Effect of probiotic and vinegar on growth performance, meat yields, immune responses, and small intestine morphology of broiler chickens.Italian Journal of Animal Science. https://doi.org/10.1080/1828051X.2018.1424570.

Andrys, R.; D. Klecker; L. Zeman and E. Marecek (2003). The effect of changed pH values of feed in isophosphoric diets on chicken broiler performance. Czech journal of Animal Science. 48: 197-206.

AOAC (2011). Association of Official Analytical Chemists, Official Methods of Analytical Chemists. $18^{\text {th }}$ ed. Arlington, VA, USA.

Araujo, Rgac.; GV. Polycarpo; A. Barbieri; K. M. Silva; G. Ventura and V. C. C. Polycarpo (2018). Performance and economic viability of broiler chickens fed with probiotic and organic acids in an attempt to replace growth-promoting antibiotics. Brazilian Journal of Poultry Science. Volume 21, Pages 001-008.

Attia, Y. A.; A. E. A. Abdel- Hamid; H. F. Ellakany; F. Bovera; M. A. Al- Harthi and S. A. Ghazaly (2013). Growing and lying performance of gapanese quail fed diet supplemented with different concutrations of acetic acid. Italian Journal of Animal Scince. Volume 12, e 37. DOI: 10.4081/ijas.2013.e37.

Attia, F. A. M.; H. S. Abd EL-Haliem; I. H. Hermes and M. M. M. A. Mahmoud (2018). Effect of organic acids supplementation on nutrients digestibility, gut microbiota and immune response of broiler chicks. Egyptian Poultry Science Journal. Volume 38, Issue I: Pages 223- 239.

Awad, W. A.; K. Ghareeb; S. Abdel-Raheem and J. Bohm (2009). Effects of dietary inclusion of probiotic and synbiotic on growth performance, organ weights, and intestinal histomorphology of broiler chickens. Poultry Science.Volume 88, Pages 49- 55. Doi: 10.3382/ps.2008-00244.

Bancroft, J. D.; A. Stevens and DR. Turner (1996). Theory and practice of histological technique. 4th ed. London, UK: Churchill Livingstone.

Boling, S. D.; J. L. Snow; C. M. Parsons and D. H. Baker, (2001). The effect of citric acid on the calcium and phosphorus requirements of chicks fed corn soybean meal diets. Poultry Science. Volume 80, Pages 783-788. DOI: 10.1093/ps/80.6.783.

Chowdhury, R.; K. M. S. Islam; M. J. Khan; M. R. Karim; M. N. Haque; M. Khatun and G. M. Pesti (2009). Effect of citric acid, avilamycin and their combination on the performance, tibia ash, and immune status of broilers. Poultry Science. Volume 88, Pages 1616-1622. Doi: 10.3382/ps.200900119 .

Coles, E. H., (1974). Veterinary clinical pathology. PP. 211- 213, W. B. Saunders, Company, Philadalphia, London, Toronto.

Dehghani, N. and R. Jahanian (2012). Interactive impacts of dietary organic acids and crude protein levels on performance and gut morphology of broiler chickens. world's Poultry Science Journal, Salvador- Bahia- Brazil.5- 9.

Dibner, J. J. and P. Buttib, (2002). Use of organic acids as a model to study the impact of gut microflora on nutrition and metabolism. Journal of Applied Poultry Research.Volume: 11, Pages: 453-463. 
Duncan, D. B., (1955). Multiple ranges and multiple F test. International. Biometric Society. Volume11, No. 1, pp. 1-42, DOI: 10.2307/3001478. https://www.jstor.org/stable/3001478.

Ebrahimi, E.; R. S. Sobhani and H. Zarghi (2017). Effect of triticale level and exogenous enzyme in the grower diet on per-formance, gastrointestinal tract relative weight, jejunal morphology and blood lipids of Japanese quail (coturnix coturnix japonica). Journal of Agricultural Science and Technology. 19(3): 569- 580.

Elmi, V. A.; S. Moradi; S. G. Harsini and M. Rahimi (2020). Effects of lactobacillus acidophilus and natural antibacterials on growth performance and salmonella colonization in broiler chickens challenged with salmonella enteritidis. Livestock Science. Volume 233, https://doi.Org/10.1016/j.

Flamand, E. M.; A. V. Duran and A. M. Albores (2014). Effect of organic acid blends in drinking water on growth performance, blood constituents and immune response of broiler chickens. Japan Poultry Science Association. Volume 51, Pages 144- 150, http:// ww.jstage. Jst. go.jp/ browse/ jpsa, doi: 10.2141/jpsa. 0120179.

Geyra, A.; Z. Uni and D. Sklan (2001). Enterocyte dynamics and mucosal development in the posthatch chick. Poultry Science. Volume 80, Issue 6, Pages 776- 782. https://doi.org/10.1093/ps/80.6.776.

Ghazalah, A. A.; A. M. Atta; KoutElkloub; M. EL. Moustafa and R. F. H.Shata (2011). Effect of dietary supplementation of organic acids on performance, nutrients digestibility and health of broiler chicks. International Journal of Poultry Science 10(3):176-184. ISSN 1682- 8356. (C) Asian network for scientific information.

Griminger, P. and C. G. Scanes (1986). Protein metabolism. In: Sturike, P. D. (ED.) Aian physiology, $4^{\text {th }}$ ed. Pd.

Haque, M. N.; K. M. S. Islam; M. A. Akbar; M. R. Karim; R. Chowdhury; M. Khatun and B. W. Kemppainen (2010). Effect of dietary citric acid, flavomycin and their combination on the performance, tibia ash and immune status of broiler. Canadian Journal of Animal Science. Volume 90, Issue 1, Pages 57-63. https://doi.org/10.4141/CJAS09048.

Heady, E. O. and H. R. Jensen (1954). Farm management economics pentice- hall inc. Englewood cliffs, N. J., USA.

Islam, M. Z.; Z. H. Khandaker; S. D. Chowdhury and K. M. S. Islam (2008). Effect of citric acid and acetic acid on the performance of broilers. Journal of Bangladesh Agricultural University, 6(2): 315320. Doi: 10.22004/ag.econ.208308

Jozefiak, D. and A. Rutkowski (2005). The effect of supplementing a symbiotic, organic acids, or $\beta$ glucanase to barley- based diets on the performance of broiler chickens. Journal of Animal and Feed Sciences. Volume 14, Pages 447- 450.

Kral, M.; M. Angeloviaova; L. Marzova; J. Tkacova and M. Kliment (2011). Probiotic and acetic acid of broiler chickens per-formance. Animal Science and Biotechnology. Volume 44, Pages 149- 152.

Kum, S.; U. Eren; A. G. Onol and M. Sandikci (2010). Effects of dietary organic acid supplementation on the intestinal mucosa in broilers. Revue de Médecine Vétérinaire. Volume 161, Issue 10, Pages 463468.

Langhout, P. (2000). New additives for broiler chickens. World Poultry. Volume: 16, Noumber 3, Pages 22- 27.

Leeson, S.; H. Namkung; M. Antongiovanni and E. Lee (2005). Effect of butyric acid on the performance and carcass yield of broile chickens.Poultry Science.Volume 84, Pages 1418-1422.

Loddi, M. M.; V. M. B. Mareas; I. S. O. Nakaghi; F. Tucci; M. I. Hannas and J. A. Ariki (2004). Mannan oligosaccharide and organic acids on performance and intestinal morphometric characteristics of broiler chickens. In proccedings of the $20^{\text {th }}$ annual symposium.ssupl. 1:45.

Minafara, C. S.; S. F. F. Marques; J. H. Stringhini; C. J. Ulhoa; C. S. Rezende; J. S. Santos; G. H. Kling (2010). Perfil bioquimico do soro de frangos de corte alimentados com dieta suplementada com alfaamylase de Cryptococcus flavus e Aspergillus niger HM 2003. Revista Brasileira de Zootecnia. Volume 39, Noumber 12, Pages 2991- 2996.

Mirderikvandi, M.; H. Khosravinia and B. P. Kavan (2019). Single and combined effects of satureja khuzistancia essentiall oils and acetic acid on productive performance, certain blood and kidney health 
- related parameters in broiler chickens. Italian Journal of Animal Science. Volume 18, Noumber 1, Pages $877-887$.

Mohammadagheni, N.; R. Najafi. and G. Najafi (2016). Effects of dietary Supplementation of organic acids and phytase on performance and intestinal histomorphology of broilers. Veterinary Research Forum. Volume 7, Issue (3), Pages 189 - 195.

Mohammadi R. N. and H. Khosravinia (2015). Acidic stress caused by dietary administration of citric acid in broiler chickens. Archives Animal Breeding. Volume 58, Issue 2, Pages 309- 315. https://doi.org/10.5194/aab-58-309.

Mohammadi, G. M.; A. Hosseindoust and I. Kim (2018). Evaluating the effect of microencapsulated blends of organic acids and essential oils in broiler chickens diet. Journal of Applied Poultry Research.Volume 24, Pages 511- 519.

Mohammed, H. A. (2016). Effect of utilization organic acid supplement on broiler (ROS-308) feeding at pre-starter and starter period breeding on basic performance parameters. International Journal of Advanced Research in biological sciences ISSN: 2348-8069. Volume 3, Issue 6. http://s-oi.org/1.15/ijarbs-2016-3- 6-10.

National Research Council (NRC), (1994). Nutrient requirement of Poultry. $9^{\text {th }}$ Rev. ed Ed., National Academy Press, Washington, DC, USA.

North, M. O., (1984).Commercial chicken production manual. 3 rd., The AVI, Publishing. CO. Inc., West. Port, Connecticut, U. S. A.

Papatsiros, V. G.; P. D. Katsoulos; K. C. Koutoulis; M. Karatzia; A. Dedousi; G. Christodoulopoulos (2013). Alternatives to antibiotics for farm animals. CAB reviews, Agriculture Veterinary Science Nutrition. Volume 8, Pages 1- 15. http://hdl.handle.net/11615/31965, DOI 10.1079/PAVSNNR20138032.

Pelicano, E. R. L.; P. A. Souza; H. B. A .Souza; D. F. Figueiredo; M. M. Boiago; S. R. Carvalho and V. F. Bordon (2005). Intestinal mucosa development in broiler chicken fed natural growth promoters. Brazilian Journal of Poultry Science. Volume 7, Noumber 4. https://doi.org/10.1590/S1516$635 \times 2005000400005$.

Pelicano, E. R.L.; P. A. Souza; H. B. A. Figueiredo; M. M. Boiago; S. R. I. Carvalho and V. F. Bordon (2011). Intestinal mucosa development in broiler chicken fed natural growth promoters. The Journal Revista Brasileira de Ciência Avícola, 7 Campina. Available on the internet: $<$ http://WWW.Scielo. br/ pdf/ rbca/v 7n 4/ 28744.

Ulaiwi, A. H.; A. Q. AL-Awadi; Z. J. M. Jawad and Z. I. Ibrahim (2017). The protective role of acetic acid against aflatoxicosis in broiler chicken. Advances in Environmental Biology. Volume 11, Pages: 26-34. http://www.aensiweb.com/AEB/.

Uni, Z., Y. Noy and D. Sklan (1999). Posthatch development of small intestinal function in the poultry. Poultry Science, 78, 215-222..

Rama Rao, S. V.; M. R. Reddy; M. V. L. N.Raju and A. K. Panda (2004). Growth, nutrient utilization and immune competence in broiler chicken fed probiotic, gut acidifier and antibacterial compounds. Indian Journal of Poultry Science. Volume 39, Issue (2): Pages 125-130.

Reitman and S. Frankel (1956). Acalorimetric method for the determination oxaloacetic transaminase and glutamic- pyruvic transaminase. American Journal of Clinical Pathology, Pages 28- 29.

Ricke, S. C. (2003). Perspective on the use of organic acids and short chain fatty acids as antimicrobials. Poultry Science. Volume 82, Issue 4, Pages 632- 639.

Rotava, R.; I. Zanella; A. K. Karkow; A. P. Dullius; L. P. da. Silva and C. C. Denardin (2008). Bioquimica sanguinea de frangos de corte alimentados com subprodutos da uva. Agrarian. Volume 1, Noumber 1, Pages 91- 104.

Sabour, S.; S. A. Tabeidian and G. Sadeghi (2019). Dietary organic acid and fiber sources affect performance, intestinal morphology, immune responces and gut microflora in broilers. Animal Nutrition. Volume 5, Issue 2, Pages 156-162. https://doi.org/10.1016/j.aninu.2018.07.004.

Saleem, G.; R. Ramzaan; F. Khattak and R. Akhtar (2016). Effects of acetic acid supplementation in broiler chickens orally challenged with Salmonella Pullorum. Turkish Journal of Veterinary and Animal Sciences. 40: 434-443. http://journals.tubitak.gov.tr/veterinary/. Doi: 10.3906/vet-1505-66. 
Samanata , S.; S. Haldar and T. K. Ghosh (2010). Comparative efficacy of an organic acid blend and bacitracin methylene disalicylate as growth promoters in broiler chickens: effects on performance, gut histology, and small intestinal milieu. Veterinary Medicine International, Pages 645- 650. Doi: $10.4061 / 2010 / 645150$.

Seifi, S.; R. Sayrafi; R. Khoshbakht and A. Gilani (2015). Effects of dietary acetic acid on intestinal microbiota, Serum components, internal organs and performance of broilers .Global Journal of Animal Scientific Research. Volume 3, Issue 2, Pages 536-543.

Sharifuzzaman, M.; F. Sharmin; M. J. Khan; M. S. R. Shishir; S. Akter; M. Afrose and H. E. Jannat (2020). Effects of Low Energy Low Protein Diet with Different Levels of Citric Acid on Growth, Feed Intake, FCR, Dressing Percentage and Cost of Broiler Production. IOSR Journal of Agriculture and Veterinary Science (IOSR-JAVS) e-ISSN: 2319-2380, p-ISSN: 2319-2372. Volume 13, Issue 3, PP 33-www.iosrjournals.org.

Snedecor, W. G. and G. W. Cochran (1982). Statical methods. (6 th ed). Iowa state college press. Iowa, USA.

Soltan, M. E. and Z. Kusainova (2012). Performance of broiler chickens in different farming with different feed conversion under Egyptian conditions. Menoufia Journal of Agriculture Research. Volume 37, Noumber 5(1), pages 1155- 1159.

SPSS, (2011). SPSS11.0 for Windows. SPSS Inc., Chicago. Standardization ministration of chaina. 2005. National feed Industry Standards for Enzyme Assays in chaina.

Stamilla, A.; A. Meesina; S. Sallemi; L. Condorelli; F. Antoci; R. Puleio; G. R. Loria; G. Cascone and M. Lanza (2020). Effects of microencapsulated blends of organics acisd (OA) and essential oils (EO) as a feed additive for broiler chicken. A focus on growth performance, gut morphology and microbiology. Animals. Volume 10, Issue 3, doi: 10.3390/ani10030442.

Sultan, A.; T. Ullah; S. Khan and R. U Khan (2015). Effect of organic acid supplementation on the performance and ileal microflora of broiler during finishing period. Pakistan journal of Zoology. Volume 47, Issue (3), Pages 635-639.

Wang, J.X. and K. Peng (2008). Developmental morphology of the small intestine of African ostrich chicks. Poultry Science, vol. 87, 2008, p. 2629-2635

Wang, J. P.; J. S. Yoo; J. H. Lee ; T. X. Zhou; H. D. Jang; H. J. Kim and I. H. Kim (2009). Effects of phenyll actic acid on production performance, egg quality parameters and blood characteristics in laying hens. Journal of Applied Poultry Research. Volume 18, Pages 203- 209.

Wickramasinghe, K. P.; N. S. B. M Attapatu and R. T. Seresinh (2014). Effects of citric acid on growth performance and nutrient retention of broiler chicken fed diets having two levels of non phosphorus and rice bran. Iranian Journal of Applied Animal Science. Volume 4, Pages 809-815 E-mail: nsbm@ansci.ruh.ac.lk

Yason, C. V.; B. A. Summers and K. A. Schat (1987). Pathogenesis of rotavirus infection in various age groups of chickens and turkeys: pathology. American Journal of Veterinary Research. Volume 48, Pages 927- 938.

Yegani, M. and D. R. Korver (2008). Factors affecting intestinal health in poultry. Poultry Science. Volume 87, Pages 2052- 2063.

Young, K. M. and P. M. Feogeding (1993). Acetic, lactic and cetric acids and PH inhibition of listeria monocytogenes Scott A. and the effect on intracellular PH. Journal of Applied Bacteriology. Volume 74, Pages 515- 520.

Youssef, I. M. I.; A. S. Mostafa and M. A. Abdel-Wahab (2017). Effects of dietary inclusion of probiotics and organic acids on performance, intestinal microbiology, serum biochemistry and carcass traits of broiler chickens. Journal of World's Poultry Research. Volume 7, Issue (2), Pages 57-71. 
تأثير إضافة حامضى الستريك ، الخليك أو مخلوطهما فى علائق كتاكيت التسمين على أداء النمو ، صفات الأبيحة وبعض القياسات الههنتولوجية للأمعاء أوليك

عاطف محمد حسن أبو عاثور ، منال كمال عبدا لطليم أبو النجا ، إيمان عاثور محمد حسين و زينب مصطفى عبد الحميد

قسم انتاج الدواجن والأسماك- كلية النزراعةـ جامعة المنوفيةـ مصر.

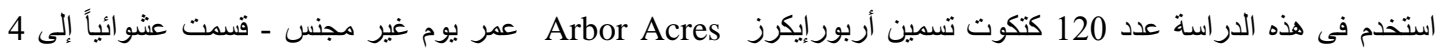

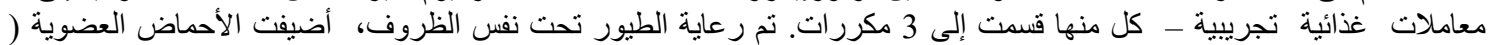

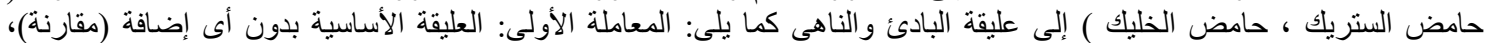

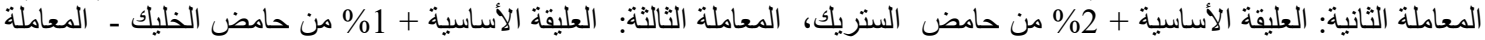

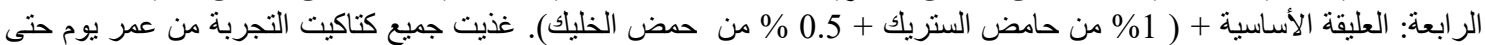

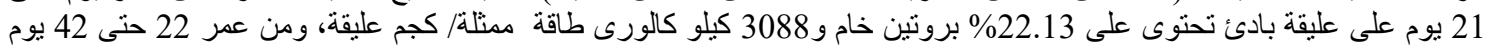

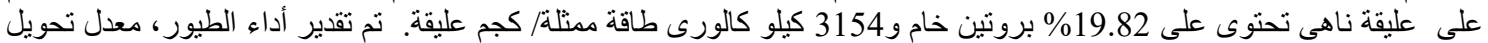

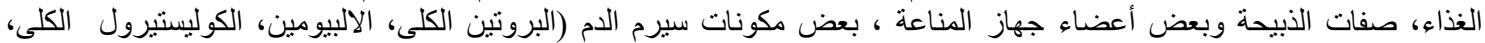

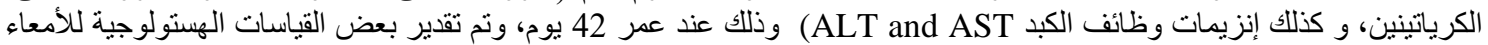
عند عمر 42 يوم، كما تم حساب الكفاءة الإنتاجبية الأوربية والكفاءة الإقتصادية.

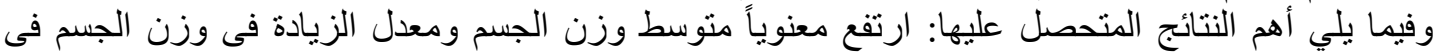

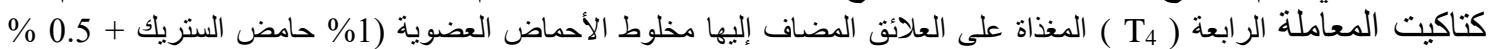

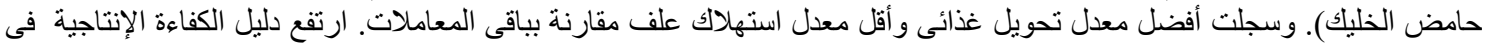

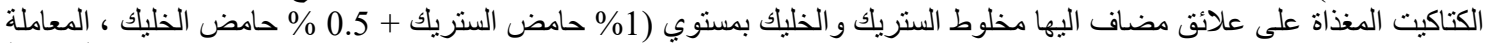

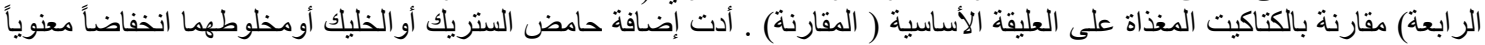

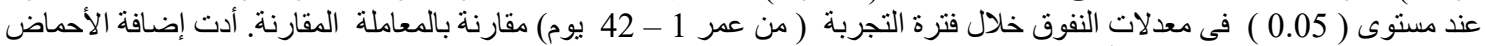

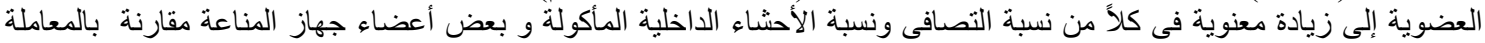

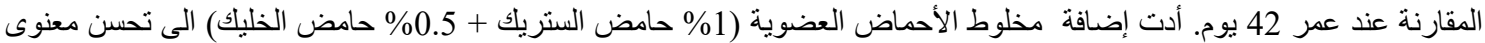

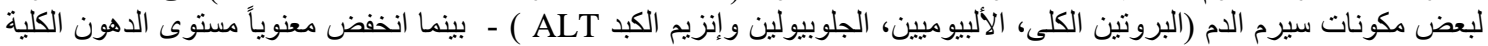

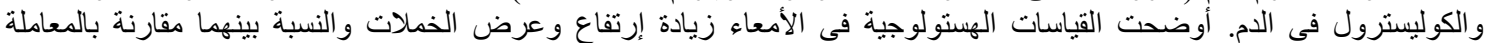

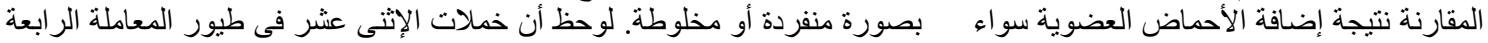

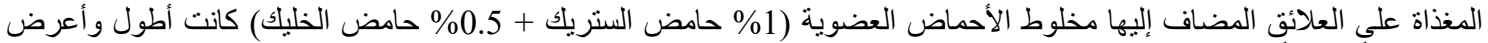

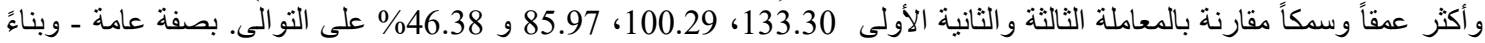

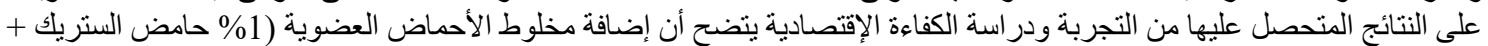

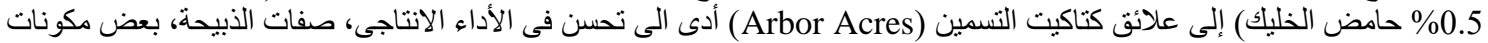

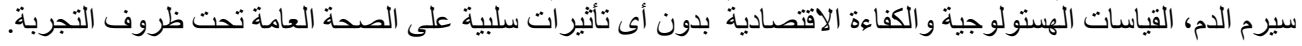

